\title{
Electrospun Nano-Fibers for Biomedical and Tissue Engineering Applications: A Comprehensive Review
}

\author{
Shokoh Parham ${ }^{1}$, Anousheh Zargar Kharazi ${ }^{1}$, Hamid Reza Bakhsheshi-Rad ${ }^{2, *}$, \\ Hamid Ghayour ${ }^{2}$, Ahmad Fauzi Ismail ${ }^{3}$, Hadi Nur ${ }^{4,5}$ and Filippo Berto ${ }^{6, *}$
}

1 Biomaterials Nanotechnology and Tissue Engineering Faculty, School of Advanced Medical Technology, Isfahan University of Medical Sciences, Isfahan 8174673461, Iran; shokoparham@gmail.com (S.P.); a_zargar@med.mui.ac.ir (A.Z.K.)

2 Advanced Materials Research Center, Department of Materials Engineering, Najafabad Branch, Islamic Azad University, Najafabad, Iran; hamidghayour70@gmail.com

3 Advanced Membrane Technology Research Center (AMTEC), Universiti Teknologi Malaysia, Skudai, Johor Bahru, Johor 81310, Malaysia; afauzi@utm.my

4 Centre for Sustainable Nanomaterials, Ibnu Sina Institute for Scientific and Industrial Research, Universiti Teknologi Malaysia, UTM Skudai, Johor 81310, Malaysia; hadi@kimia.fs.utm.my

5 Central Laboratory of Minerals and Advanced Materials, Faculty of Mathematics and Natural Science, Universitas Negeri Malang, Malang 65145, Indonesia

6 Department of Mechanical and Industrial Engineering, Norwegian University of Science and Technology, 7491 Trondheim, Norway

* Correspondence: rezabakhsheshi@gmail.com or rezabakhsheshi@pmt.iaun.ac.ir (H.R.B.-R.); filippo.berto@ntnu.no (F.B.)

Received: 31 March 2020; Accepted: 23 April 2020; Published: 6 May 2020

\begin{abstract}
Pharmaceutical nano-fibers have attracted widespread attention from researchers for reasons such as adaptability of the electro-spinning process and ease of production. As a flexible method for fabricating nano-fibers, electro-spinning is extensively used. An electro-spinning unit is composed of a pump or syringe, a high voltage current supplier, a metal plate collector and a spinneret. Optimization of the attained nano-fibers is undertaken through manipulation of the variables of the process and formulation, including concentration, viscosity, molecular mass, and physical phenomenon, as well as the environmental parameters including temperature and humidity. The nano-fibers achieved by electro-spinning can be utilized for drug loading. The mixing of two or more medicines can be performed via electro-spinning. Facilitation or inhibition of the burst release of a drug can be achieved by the use of the electro-spinning approach. This potential is anticipated to facilitate progression in applications of drug release modification and tissue engineering (TE). The present review aims to focus on electro-spinning, optimization parameters, pharmacological applications, biological characteristics, and in vivo analyses of the electro-spun nano-fibers. Furthermore, current developments and upcoming investigation directions are outlined for the advancement of electro-spun nano-fibers for TE. Moreover, the possible applications, complications and future developments of these nano-fibers are summarized in detail.
\end{abstract}

Keywords: electrospinning; fabrication; parameters effect; nano-fibers; drug delivery; wound dressing

\section{Introduction}

As one-dimensional nano materials, nano-fibers have attracted a lot of attention from researchers and found widespread applications [1]. Compared to many other common base materials, nano fibers have numerous important characteristics, including a very thin diameter (a 1000 times thinner than the diameter of human hair), three dimensional topography, flexible surface capabilities, large surface 
area, adjustable porosity, and good mechanical characteristics such as tensile strength and stiffness [2]. Owing to the progress of nano-fiber technology, an interesting point in this regard is that a large number of different materials can be utilized for the fabrication of these fibers. Such materials include synthetic and natural polymers, metals and their oxides, composite as well as carbon based nano-materials [3]. Additionally, it is possible to modify the surface of nano-fibers together with their bulk properties for different purposes, and this result in a variety of physical qualities and many different applications and usages [4]. The nano-fiber production methods are categorized into two main groups, namely top-down and bottom-up techniques. In a top-down procedure, like mechanical and chemical treatment of wood pulp, nano-fibers are obtained by breaking down the bulk material. Top-down techniques are usually used for obtaining cellulose nano-fibers or CNFs [5]. On the other hand, in bottom-up methods such as electro-spinning, drawing, self-assembly, template synthesis, and phase separation, nano-fibers are fabricated from constituting molecules. Due to their distinctive features that make them quite appropriate for drug delivery systems and biomedical engineering, nano-fibers have been the target of attention of many scientists and researchers [6,7]. These unique characteristics include high porosity, tunable pore size, high surface to volume ratio, as well as morphological correspondence with the extra-cellular matrix. Polymeric fibrous structures were identified as suitable candidates for drug-release systems, and fibrous polymer structures have been prepared by a variety of methods like the electro-hydrodynamic techniques (EHD). In the electro-hydrodynamic methods, electrostatic forces are employed for the production of fibers or particles with an adjustable micro-structure [6]. As an outstanding cost-efficient EHD method, electro-spinning has found vast applications in the industry and laboratory for fiber fabrication. In this method, pharmaceutical biomolecules or agents are directly encapsulated within the fibers, leading to their protection from the environmental parameters and, simultaneously, to the release control [5]. This approach is an extensively employed method compared to other fabrication approaches, due to such properties as low cost, simplicity, and potential of mass production. On top of that, it is feasible to control the composition, orientation and diameter of the nano-fibers in accordance with the desired application [8]. When exploited for the fabrication of wound dressing, electro-spinning offers many benefits, including adjustable porosity, great surface-to-volume ratio, and the capacity of imitating the tissue extra-cellular matrix [3]. As a consequence of these characteristics, on one hand, cytocompatibility will be enhanced, and on the other hand, there will be a high potential of keeping the wound moisture microenvironment and absorbing the wound [9]. According to literature, an electro-spinning setup consists of four basic parts: a glass syringe that contains a polymer solution, a metallic needle, a power supply, and a metallic collector with an adaptable shape [10]. The approach initiates with the motion of electric charges in the polymer solution by means of the metallic needle. Subsequently, the polymer solution becomes instable as the charges are induced on the polymer droplet [11]. Simultaneously, an opposing force to the surface tension is generated by the reciprocal repulsion of the charges. Eventually, the polymer solution flow will be aligned with direction of the electric field. More escalation in the electric field results in the deformation of the droplet shape from spherical to conical. At this point, ultrafine nano-fibers will appear through the conical polymer droplet. These fibers are gathered on the metallic collector that is maintained at an adjusted distance [2]. Essentially, as soon as the polymer solution presented enough cohesive force, a constant charge jet could be created. During the procedure, the liquid jet whipping in the path of the collector will be induced by the inner and outer charge forces [11]. The whipping motion causes the stretching of the polymer chains inside the solution and their sliding past each another, which consequently leads to the formation of fibers that can aptly be called nano-fibers due to their very small diameters [12]. In the recent years, this method has attracted a lot of attention from biomedical researchers from all over the world for fabricating micro- and nano-structures to be applied as drug carriers and scaffolds. In electro-spinning, in order to produce polymeric and non-woven fibers, an electrical field is applied [13]. Three-dimensional scaffolds with different sizes and shapes can be obtained via such a versatile technique. An electro-spinning apparatus setup comprises three main components: a grounded metal collector, a solution reservoir associated with a spinneret, and a high 
voltage power supply [14]. The properties of the solution and the process parameters are important for the fibers physical, morphological, and biomechanical performance. This cutting-edge technology has a high potential in controlled drug delivery and tissue engineering because an extensive range of materials can be used [15].

There are many different electro-spinning methods such as coaxial, single jet, emulsion, and needleless. Among these, the coaxial electro-spinning or core-shell systems have a multidimensional nature [2]. To illustrate, it is possible to fabricate a continuous double layer of nano fibers with this method. For this purpose, two materials that encapsulate different drug types are electro-spun in a simple one-stage process [16]. On-demand biomaterial platforms for drug delivery and tissue engineering have been provided by this technique through the generation of structures that have two separate parts, an inner part, or core, that is completely enclosed by an outer part, or shell $[17,18]$. Such a porous structure possesses a morphology that can be beneficial for wound dressing and also drug delivery. In the case of full thickness wounds, since the local vessels have been destroyed, the blood supply encounters obstacles which will inevitably delay the healing of the wound as well as the delivery of the drug [19]. Moreover, wound dressing polymers should be as flexible as the skin and, at the same time, should be capable of loading and releasing the drugs in a controlled mode. Another noteworthy factor that is essential in therapeutic procedures is the reduction of overall dose and this is offered by nano-fibers as they enhance the drugs bioavailability and dissolution [20]. The electro-spun nano-fibers can be exploited for different purposes; in addition to drug delivery systems, tissue engineering, and wound dressing, it has been used in many different fields of biomedicine as can be seen in Figure 1 [21]. Nevertheless, even with the extensive utilization of the electro-spinning approach, the comprehension of this technique is very limited, even now. Hence, the recent review article covers the research carried out on the electro-spinning method, optimization parameters, and pharmaceutical uses of the nano-fibers (range of 50-900 nm) obtained via electro-spinning with the aim of yielding a complete understanding of this approach for tissue engineering (TE) applications. In the subsequent sections of this review article, a comprehensive summery is offered on the cell viability, antimicrobial activity and in vivo analysis of the electro-spun nano-fibers.

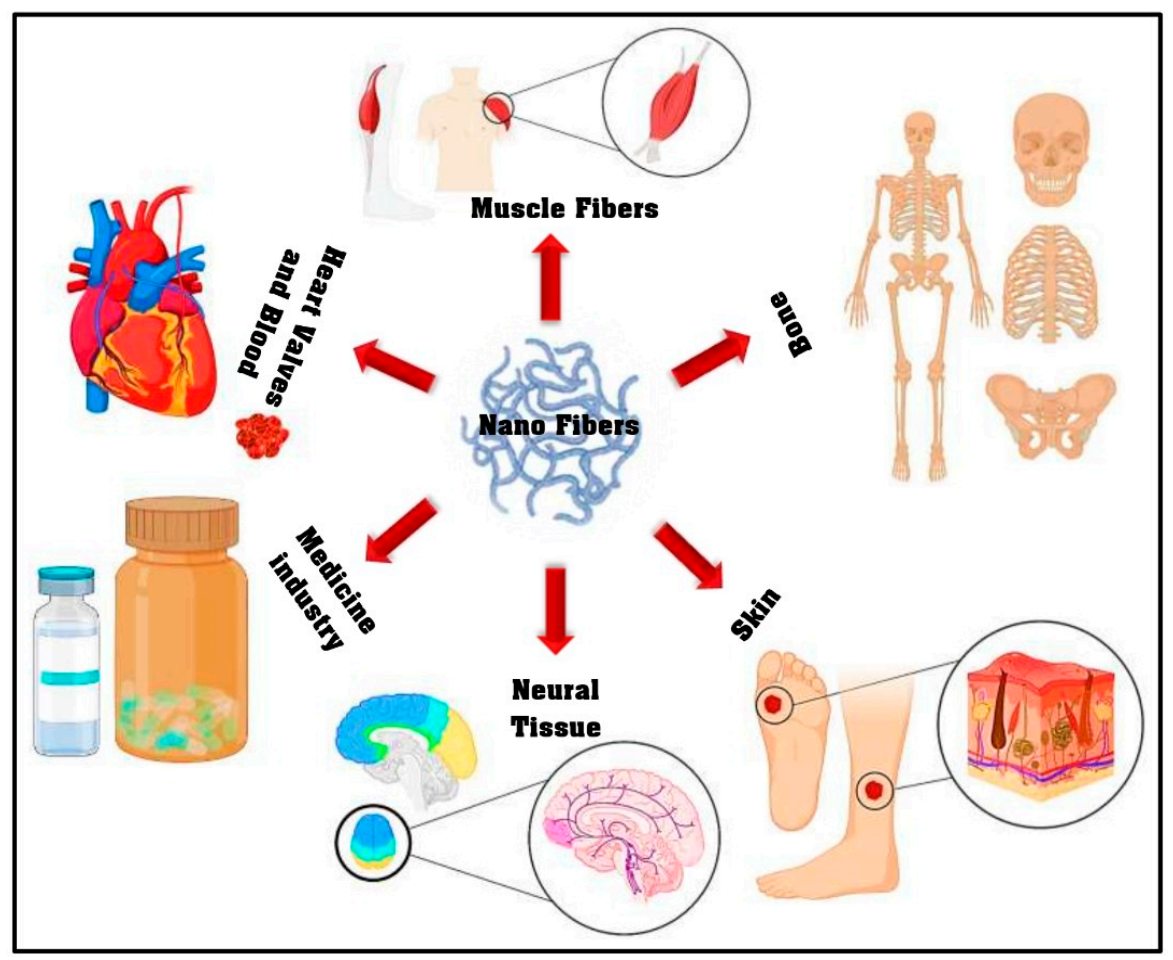

Figure 1. The electro-spun nano-fiber application in different biomedical fields (adapted from Miguel et al. [21]). 


\section{Electro-Spinning for Biomedical Applications}

There is a lot of research investigating antimicrobial biomedical application [22-27]. Many researchers have studied the electro-spinning method for biomedical application [28-37]. Multi-level structured nano-fibers have been successfully developed via electro-spinning for different purposes through the use of such diverse materials as polyacrylic acid, silica nylon, polyacrylonitrile, SU-8 2100, polycarbonate, polybenzimidazole, polyurethane, polyethylene oxide, polystyrene, polyvinyl alcohol, gelatine, cellulose, chitosan, chitin, and carbon nano-materials [36-38]. Electro-spun fibers with various shapes such as cylindrical, hollow, porous, ribbon beads, patterned mats, and helices have been developed through the use of different polymers by numerous research teams [39]. The electro-spinning methods include such techniques as blend, coaxial, needleless, and emulsion (Figure 2). Among these, coaxial electro-spinning is used more extensively for biomedicine applications such as wound dressing [21,33]. Due to the production of non-defect nano-fibers, the electro-spinning parameters should be highlighted to attain a significantly better understanding of the electro-spinning approach and the effects of virtually all of these types of regulating parameters. Therefore, Table 1 will help to provide an overview of the parameters of electro-spinning different polymers such as the solvent, tip collector distance, and voltage which have significant effects on the quality of the fabricated nano-fibers [40-54]. Table 2 depicts the effects of the electro-spinning equipment setup and their corresponding parameters on the characteristics of polymer-based electro-spinning [55-74]. The fiber morphology is a factor of great significance to guide the application of electro-spun nano-fibers in numerous manufacturing areas. To be able to enhance and/or attain various morphologies, numerous electro-spinning equipment setups and their corresponding experimental parameters including solvent and voltage should be evaluated, since these factors have a significant effect on the cell adhesion and proliferation as well as antibacterial performance of polymers. Hence, these characteristics are summarized in Table 2 with the aim of fulfilling polymer-based electro-spinning applications requirement.

Table 1. Parameters of electro-spinning of different polymers.

\begin{tabular}{|c|c|c|c|c|c|}
\hline Polymer & Solvent & Voltage & $\begin{array}{l}\text { Tip Collector } \\
\text { Distance }\end{array}$ & $\begin{array}{c}\text { Fiber } \\
\text { Diameter }\end{array}$ & Ref. \\
\hline PCL (Polycaprolactone) & Formic acid/acetic acid & $12 \mathrm{kV}$ & $12.5 \mathrm{~cm}$ & $266 \mathrm{~nm}$ & [40] \\
\hline PVA (Polyvinyl alcohol) & Deionized water & $22 \mathrm{kV}$ & $10 \mathrm{~cm}$ & $240 \mathrm{~nm}$ & [41] \\
\hline PLA (Poly(lactic acid)) & Acetone & $20 \mathrm{kV}$ & $15 \mathrm{~cm}$ & $757 \mathrm{~nm}$ & [42] \\
\hline PLLA (poly (1-lactic acid) & Chloroform and acetone & $20 \mathrm{kV}$ & $12 \mathrm{~cm}$ & $150 \mathrm{~nm}$ & [43] \\
\hline Chitosan & Acetic acid & $40 \mathrm{kV}$ & - & $130 \mathrm{~nm}$ & [44] \\
\hline Silk fibroin & $\mathrm{CaCl}_{2} / \mathrm{H}_{2} \mathrm{O} / \mathrm{C}_{2} \mathrm{H}_{5} \mathrm{OH}$ & $12.5 \mathrm{kV}$ & $21 \mathrm{~cm}$ & $700 \mathrm{~nm}$ & [45] \\
\hline Collagen & Acetic acid & $15-20 \mathrm{kV}$ & $19-21 \mathrm{~cm}$ & $100-600 \mathrm{~nm}$ & [46] \\
\hline Hyaluronic acid (HA) & Deionized water & $22 \mathrm{kV}$ & $15 \mathrm{~cm}$ & $200 \mathrm{~nm}$ & [47] \\
\hline Poly hydroxyl butyrate & Chloroform: Dichloroethane & $20 \mathrm{kV}$ & $7.5 \mathrm{~cm}$ & $280 \mathrm{~nm}$ & [48] \\
\hline Cellulose Acetate & Acetone & $12 \mathrm{kV}$ & $10 \mathrm{~cm}$ & $801 \mathrm{~nm}$ & [49] \\
\hline Poly (glycerol sebacate) & $\begin{array}{c}\text { Chloroform/ } \\
\text { dimethyl formamide }\end{array}$ & $9 \mathrm{kV}$ & $30 \mathrm{~cm}$ & $590 \mathrm{~nm}$ & [50] \\
\hline Elastin & Hexafluoro-2-propanol & $10 \mathrm{kV}$ & $12 \mathrm{~cm}$ & $605 \mathrm{~nm}$ & [51] \\
\hline Gelatin & 2,2,2-trifluoroethanol (TFE) & $10 \mathrm{kV}$ & $13 \mathrm{~cm}$ & $200-300 \mathrm{~nm}$ & [52] \\
\hline $\begin{array}{l}\text { Poly (ethylene-co-vinyl } \\
\text { alcohol) }\end{array}$ & $\begin{array}{l}\text { Deionized water/isopropyl } \\
\text { alcohol (IPA) }\end{array}$ & $15 \mathrm{kV}$ & $15 \mathrm{~cm}$ & $500 \mathrm{~nm}$ & [53] \\
\hline Chitin & $\begin{array}{c}\text { 1,1,1,2,2,2-hexafluoro-2-propanol } \\
\text { (HFIP) }\end{array}$ & $15 \mathrm{kV}$ & $7 \mathrm{~cm}$ & $100 \mathrm{~nm}$ & [54] \\
\hline
\end{tabular}


Table 2. Effects of electro-spinning equipment setup and their corresponding parameters on the characteristics of polymer-based electro-spinning.

\begin{tabular}{|c|c|c|c|c|c|c|}
\hline Polymer & $\begin{array}{l}\text { Electrospinning } \\
\text { Technique }\end{array}$ & Fiber Diameter & Application & Condition & Results & Ref. \\
\hline Collagen + Silk fibroin $(\mathrm{SF})$ & Blend & $320-360 \mathrm{~nm}$ & Wound healing & In vitro & The cell attachment is 300 cells $/ 0.53 \mathrm{~mm}^{2}$ & [55] \\
\hline PCL & Blend & $250 \mathrm{~nm}$ & Wound healing & In vitro & The duration of the cell culture proliferation is around 7 days & [56] \\
\hline Poly (L-lactide) + Poly (D-lactide) & Blend & $300 \mathrm{~nm}$ & Wound healing & In vitro and In vivo & $\begin{array}{l}\text { Crystallinity } 61 \% \text { - } 4 \text { week (Before implantation) and } 49 \% \\
\text { (after implantation) }\end{array}$ & [57] \\
\hline Chitosan + PCL & Blend & $177 \mathrm{~nm}$ & $\begin{array}{l}\text { Acute and chronic wound } \\
\text { healing }\end{array}$ & In vitro and In vivo & $45 \%$ wound recovery in during 6 days & [58] \\
\hline PCL + BC (Bacterial cellulose) & Blend & $400 \mathrm{~nm}$ & Wound dressing - & In vitro & The $100 \%$ cell viability has been appeared in during $72 \mathrm{~h}$ & [59] \\
\hline Carboxyethyl chitosan (CECS) + PVA & Blend & $131-456 \mathrm{~nm}$ & Wound dressing & In vitro & The adhesion study of the L929 cells ( $48 \mathrm{~h}$ ) & [60] \\
\hline Chitosan/poly ethylene oxide & Blend & $60-120 \mathrm{~nm}$ & Wound dressing & In vitro & The viscosity is 2.25 Pa.s and electric conductivity is $3 \mathrm{mS} / \mathrm{cm}$ & [61] \\
\hline $\begin{array}{l}\text { PEG-Lysozyme PEG-Bovine Serum Albumin } \\
\text { (BSA) + PCL }\end{array}$ & Co-axial & $571 \mathrm{~nm}$ & Wound healing & In vitro & $50 \%$ drug release in during 24 day & [62] \\
\hline PLA + collagen & Co-axial & $168 \mathrm{~nm}$ & Wound dressing & In vitro & $\begin{array}{c}\text { The cell viability has been increased during } 14 \text { days and } \\
\text { antimicrobial efficiency against S. epidermis, P. aeruginosa and } \\
\text { E. coli }\end{array}$ & [63] \\
\hline PLA + Chitosan (CS) & Co-axial & $236 \mathrm{~nm}$ & Wound healing & In vitro & The antibacterial efficiency against E. coli bacteria & [64] \\
\hline Chitosan + PEG & Blend & $50-200 \mathrm{~nm}$ & Wound healing & In vivo & The time of the cells spreading is around 3 days & [65] \\
\hline $\begin{array}{l}\text { Poly-(3-hydroxybutyrate-co-3-hydroxyvalerate) } \\
\text { (PHBV)/Ag nanofibers poly }\end{array}$ & Emulsion & $603 \mathrm{~nm}$ & Wound healing & In vitro & The drug release of the AgNPs is $0.55 \mathrm{ppm}$ during 30 days & [66] \\
\hline (Llactide-co-D, L-lactide) + poly (vinyl alcohol) & Blend & $275 \mathrm{~nm}$ & Wound dressing & In vitro & $\begin{array}{l}\text { The anti-bacterial efficiency against E.coli and S.aureus, the } \\
\text { tensile stress is around } 19 \mathrm{MPa} \text { and Young's modulus is around } \\
532 \mathrm{MPa} \text { and SNL 76/7 fibroblast cell line culture shows good } \\
\text { proliferation. }\end{array}$ & [67] \\
\hline Dimethyloxalylglycine (DMOG) PCL/Col I & Co-axial & $200-500 \mathrm{~nm}$ & Wound healing & In vivo & $\begin{array}{c}53 \% \text { drug release of nanofiber during } 12 \mathrm{~h} \text { and } 72 \% \text { during } 24 \mathrm{~h} . \\
\text { drug release of core/shell nanofibers: } 17 \% \text { during } 12 \mathrm{~h} \text { and } 36 \% \\
\text { during } 24 \mathrm{~h}\end{array}$ & [68] \\
\hline Polyhydroxybutyrate (PHB) + Gelatin (GEL) & Blend & $80 \mathrm{~nm}$ & Wound healing & In vitro and in vivo & The $71.8 \%$ degradation rate during $12 \mathrm{~h}$ & [69] \\
\hline Gelatin/Oleoyl Chitosan (OC) & Blend & $150-400 \mathrm{~nm}$ & $\begin{array}{l}\text { Full-Thickness Excisional } \\
\text { Wound Healing }\end{array}$ & In vitro & The swelling is around $380 \%$ and the water contact angle is $80^{\circ}$ & [70] \\
\hline Chitosan + PEO & Co-axial & $250 \mathrm{~nm}$ & Wound healing & In vitro & The tensile strength is $4.0 \mathrm{MPa}$ and porosity is around $84 \%$ & [71] \\
\hline $\begin{array}{l}\text { Gelatin + poly-methyl vinyl ether-altmaleic } \\
\text { anhydride (PMVE/MA) + nano zinc oxide }\end{array}$ & Emulsion & $500-700 \mathrm{~nm}$ & Wound healing & In vivo & $99 \%$ wound healing during 10 days & [72] \\
\hline Dimethyloxalylglycine (DMOG) + PLLA & Co-axial & - & $\begin{array}{l}\text { Diabetic wound, chronic } \\
\text { wound }\end{array}$ & In vivo & $97 \%$ wound healing happened during 15 days & [73] \\
\hline $\begin{array}{l}\text { Polyurethanes without dendrimer + } \\
\text { Polyurethanes with NO-releasing dendrimer }\end{array}$ & Co-axial & $393 \mathrm{~nm}$ & Wound dressing & In vitro & The NO release during $9 \mathrm{~h}$ & [74] \\
\hline
\end{tabular}




\subsection{Blend Electro-Spinning}

Blend or single jet electro-spinning, as the most common electro-spinning method, involves the mixing of all chemical compounds and polymer components by a single-solvent system. It is possible to encapsulate lipophilic and hydrophilic drugs, as well as biomolecules (like proteins, RNA, and DNA) within the fibers by blend electro-spinning $[75,76]$. Due to the exceptional characteristics of the fibers, this method is quite effective for the generation of drug delivery systems (DDSs) with sustained diffusion, minimum dosage and local delivery of drugs that will reduce systematic absorption. As a consequence, side effects that result from high dosages can be limited or even avoided. Compared to other methods and DDSs, electro-spun fibers offer reduced initial burst release [77]. Nevertheless, there are some limitations of blend electro-spinning, specifically in terms of drug delivery. For instance, the organic solvents that are used in electro-spinning denature sensitive pharmaceutical proteins, molecules or even DNA. This results in the loss of bioactivity which, in turn, reduces the efficiency of these molecules and proteins [78]. Additionally, due to the electric charge of most bioactive molecules and their ability to migrate to the surface of the fiber (as a result of electrostatic repulsion), distribution within the fibers might be casual [79]. This may ultimately result in the burst release of the encapsulated materials when the fibers are located in an aqueous medium [80]. This technique has been used by many researchers for the improvement of tissue engineering and biomedical applications [78-81]. To illustrate, bombyx mori silk fibroin nano-fibers obtained by blend electro-spinning were used in wound healing [82]. Poly (L-lactide) + Poly (D-lactide) and Polycaprolactone (PCL) nano-fibers prepared by the same method have also been used for enhancing biomedical application [83,84]. In another study, cellulose acetate (CA) nano-fiber was employed as wound dressing [85]. A simple technique involving a combination of calcination and electro-spinning was exhibited by Kurniawan et al., [86] who fabricated electro-spun poly (N-vinylpyrrolidone) mats that were decorated with gold nano-particles. Due to the electrostatic interactions of the positively charged amino-silane groups with the negatively charged gold nano-particles, the gold nano-particles were decorated on the nano-fibers' surfaces to improve the antimicrobial activity of the nano-fibers [86]. In blend electro-spinning, the bioactive molecules dispersed or dissolved in the polymeric solution are encapsulated. After that, when the mixture is electro-spun, hybrid fibers will be obtained [82]. As the biomolecules are entrapped within the fibers, the release will be sustained and an early burst release will be prevented [82]. Li et al. prepared an electro-spun nano-fibrous mesh by mixing sodium alginate and organic rectorite (OREC) (which is a bacterial inhibitor) with polyvinyl alcohol (PVA). The in vitro results showed that the nano-fiber's bactericidal activity was improved by OREC [87]. Chouhan et al. [88] depicted non-mulberry silk fibroin based (NMSF) electro-spun mats functionalized with epidermal growth factor (EGF) and ciprofloxacin $\mathrm{HCl}$ as potential wound dressing. Their findings exhibited that the NMS-based mats were cytocompatible, had a high water retention capacity, exhibited antibacterial activity and sustained drug release. Although the blend electro-spinning method is an adaptable and versatile approach, an important drawback of the fibers obtained by this method is the reduction of performance and activity of the embedded biomolecules which accommodates the system's healing rate [75]. To overcome this limitation, co-axial and emulsion electro-spinning methods have been utilized for fabricating core-shell fibers. The nano-fibers achieved in this manner show an accelerated bioactive/drug molecule encapsulation efficiency and avoid the instantaneous interaction of these biomolecules with the outer media, which is essential for the retention of the biological activity of unstable biological agents [2].

\subsection{Coaxial Electro-Spinning}

Contrary to the blend electro-spinning technique, coaxial electro-spinning is a new variation of the electro-spinning technique which produces multi-layered core-sheath structured nano-fibers (or coaxial fibers) and includes the utilization of two concentrically assembled nozzles linked to an excessive amount of voltage source [89]. The polymeric solution is led through their corresponding reservoirs into the coaxial spinneret by using two individual pumps while controlling the solution flow rate [90]. The mixing of the solvents will be prevented by this setup and the interface of the solutions occurs 
only at the tip of the spinneret, where the edges of the concentric nozzles end. Numerous research teams have developed and utilized a unique spinneret to facilitate this process [89-91]. Fibers with a core-shell structure will be obtained by this setup and these coaxial fibers have a potential to be used as pharmaceutical as well as other sensitive biological molecules carriers, and they are also capable of protecting these biomedical substances from environmental parameters and controlling their release mechanism [92]. Simultaneously, coaxial electro-spinning permits the single-stage co-encapsulation of two or more therapeutic additives in various sections of the coaxial fibers, thus providing us with a multiple or dual drug release system [64]. One of the most interesting advantages of coaxial electro-spinning compared to the blend method is that the former uses two different media, hence minimizing the interaction between the solutions and preserving the internal media, where the sensitive biomolecules or pharmaceutical agents are chiefly distributed, from the environment [92]. Moreover, the core and shell polymer concentrations as well as the ratio of core/sheath solution flow rates are the most significant factors in the coaxial electro-spinning method. Lower flow rates of the inner solution have been designated as more promising for achieving a stable procedure [93]. Both core and shell parts of the fibers can be used for encapsulating therapeutic agents and a proper selection of a drug-polymer-solvent system can significantly improve drug encapsulation efficiency and yield a multiple time-step drug release system in which different drugs are released either simultaneously or one at a time [94]. Another interesting technique involves the utilization of the same core and shell solvent while dissolving the therapeutic agent only in the core solution [95]. In this manner, the distribution of the agent near the fiber core will be restrained and, consequently, the diffusion of the drug in the polymeric matrix will be postponed [94]. PEG/PVA core-shell fibers were used for encapsulating salicylic acid while acetylsalicylic acid (ASA) loaded PCL was electro-spun upon a cylindrical collector to obtain tubular scaffolds for sustained delivery of anti-platelet and anti-inflammatory agents [96]. Maleknia et al. reported that the core-shell polyurethane (PU)/chitosan (Cs) nano-fibers can be used as a potential platform for bioactive scaffolds in tissue engineering. In coaxial electro-spinning, different syringe pumps and coaxial needles are used for the generation of both the core, in which the bioactive constituents are generally encapsulated, and the shell that offers protection and ensures the sustainable release of the loaded molecules [97]. In a study by Maleki et al., the capacity of coaxially electro-spun tetracycline hydrochloride-loaded PLGA core-shell nano-fibers was compared with blend fibers (prepared by using the same materials) for sustained drug release [98]. Other researchers prepared wound dressing by using simvastatin, ciprofloxacin, and other drugs via coaxial electro-spinning. Most researchers confirmed that the core-shell nanostructures exhibited better results in terms of controlled drug release [92,99]. Coaxially electro-spun fibers were employed for encapsulating sensitive growth factors (GFs) in the fiber core. According to the in vivo studies, the GFs sustained release was authenticated via applying polyurethane core-shell fibers, which revealed an activity very similar to that of the fresh GFs [100]. Coaxial electro-spinning has been also utilized for incorporating platelets into the fibers to function as GF reservoirs [101]. Likewise, the loading of nucleic acids with or without extra carriers including plasmids seemed to be created through electro-spinning [102]. Synthetic nano-fibered polymer/DNA composite scaffolds composed mainly of a poly (D,L-lactide)-poly (ethylene glycol) (PLA-PEG) block copolymer and poly(lactide-co-glycolide) (PLGA) random copolymer were used for loading plasmid DNA. Their obtained results pointed out that the DNA released immediately from these scaffolds has the ability of cell attachment and effectively protects the protein b-galactosidase [103].

\subsection{Emulsion Electro-Spinning}

In emulsion electro-spinning, the drug aqueous protein solution is emulsified in a polymer solution. Emulsion electro-spinning can be used to construct core-shell nano-fibers without requiring a specific needle setup [104]. The technique involves chemical separation. An emulsion is created within a single solution and consequently, as the solvent evaporates from the electro-spun fibers, the emulsified droplets are organized into two separate phases [105]. Wang et al. produced biodegradable 
nano-fibrous polycaprolactone/hyaluronan-epidermal growth factor scaffolds by using emulsion electro-spinning. In vitro examination of human skin keratinocytes ( $\mathrm{HaCaT})$ and fibroblasts on these scaffolds exhibited a considerable influence of hyaluronan and epidermal growth factor (EGF) on cell adhesion and growth. Additionally, their results indicated that an elevated reproduction of completely functional skin appeared to be enhanced by the EFG-loaded PCL/hyaluronan scaffolds [106]. In a study by Qi et al. [107], nano-fibers with beads-in-string structures via emulsion electro-spinning from either water-in-oil $(\mathrm{W} / \mathrm{O})$ or oil-in-water $(\mathrm{O} / \mathrm{W})$ emulsion. Ca-alginate microspheres, that work as reservoirs for hydrophilic drugs, were prepared in a reverse emulsion method and then incorporated into PLLA fibers by electro-spinning. They encapsulated the bovine serum albumin (BSA) into the microspheres and demonstrated that BSA was generated from nano-fibers with lengthy periods of release pattern and less rapid release rates compared with the bare Ca-alginate microspheres [107]. Hu et al. assessed the drug release behavior of small molecule drugs from nano-fibrous scaffolds produced by emulsion electro-spinning of either metoprolol tartrate (MPT) or metformin hydrochloride (MH) with poly (3-hydroxybutyric acid-co-3-hydroxyvaleric acid) (PHBV) or poly ( $\varepsilon$-caprolactone) (PCL). According to their results, PCL was demonstrated to be a better drug delivery carrier than PHBV, and MPT-incorporated nano-fibers showed less burst release [108]. Yan et al. evaluated the incorporation of Rhodamine B and BSA into nano-fibers by the emulsion electro-spinning method with controlled drug delivery [109]. In other research projects, smooth core-sheath nano-fibers were fabricated via electro-spinning a W/O emulsion with the aqueous phase consisting of water-soluble drugs solution in water and the oily phase consisting of a chloroform solution of an amphiphilic PEG/PLLA diblock copolymer [110]. Emulsion electro-spinning has been regarded as a promising approach for preparing nano-fibrous materials/scaffolds for GF delivery [111,112].

\subsection{Needleless Electro-Spinning}

In this method, the polymer solution is kept in the tank and a uniform distribution is provided on the electrode through rotation. An electrostatic field is employed for creating fibers without implementing needles [113]. Maver et al. addressed the needleless electro-spinning of carboxymethyl cellulose/polyethylene oxide (CMC/PEO)/plant extract blend aqueous solutions for the purpose of fabricating a cellulose-based wound dressing material that would be appropriate for curing severe wounds. The released study and cell viability tests indicated the promising potential of the product to be used for wound care [114]. Jun-Jye Ng and Pitt Supaphol investigated the production of polymer nano-fiber mats through needleless electro-spinning of poly (caprolactone) (PCL), poly (lactic acid) (PLA), and poly (vinyl alcohol) (PVA) [115]. Wang et al. prepared large scale ultrafine chitosan hybrid nano-fibers containing $\mathrm{TiO}_{2}$ and/or Ag nanoparticles by needleless electro-spinning and found that the chitosan hybrid nanofibers showed excellent antibacterial activity. It has been reported that nano-fibers from inorganic polymers have been successfully electro-spun by using mixed solutions of a non-inorganic polymer and an inorganic polymer [116]. The needleless electro-spinning of chitosan nano-fiber has been accomplished using a blend of chitosan with another polymer such as poly (ethylene oxide) (PEO) [117]. The poly (vinyl alcohol) (PVA) and poly vinyl pyrrolidone (PVP) were usually fabricated by needleless electro-spinning method [118,119]. In recent years, researchers have paid more attention to needleless electro-spinning for obtaining antimicrobial wound dressings through the use of antimicrobial inorganic agents like metal and metal oxide nanoparticles [119,120]. On the other hand, these inorganic agents have been reported to generate free radicals through their antimicrobial mechanism, leading to their higher level of toxicity [121-125]. The electro-spinning methodologies of different electrospinning methods (blend electro-spinning, coaxial electro-spinning, emulsion electro-spinning and needleless electro-spinning) are shown in Figure 2 [75,92,104,126]. 


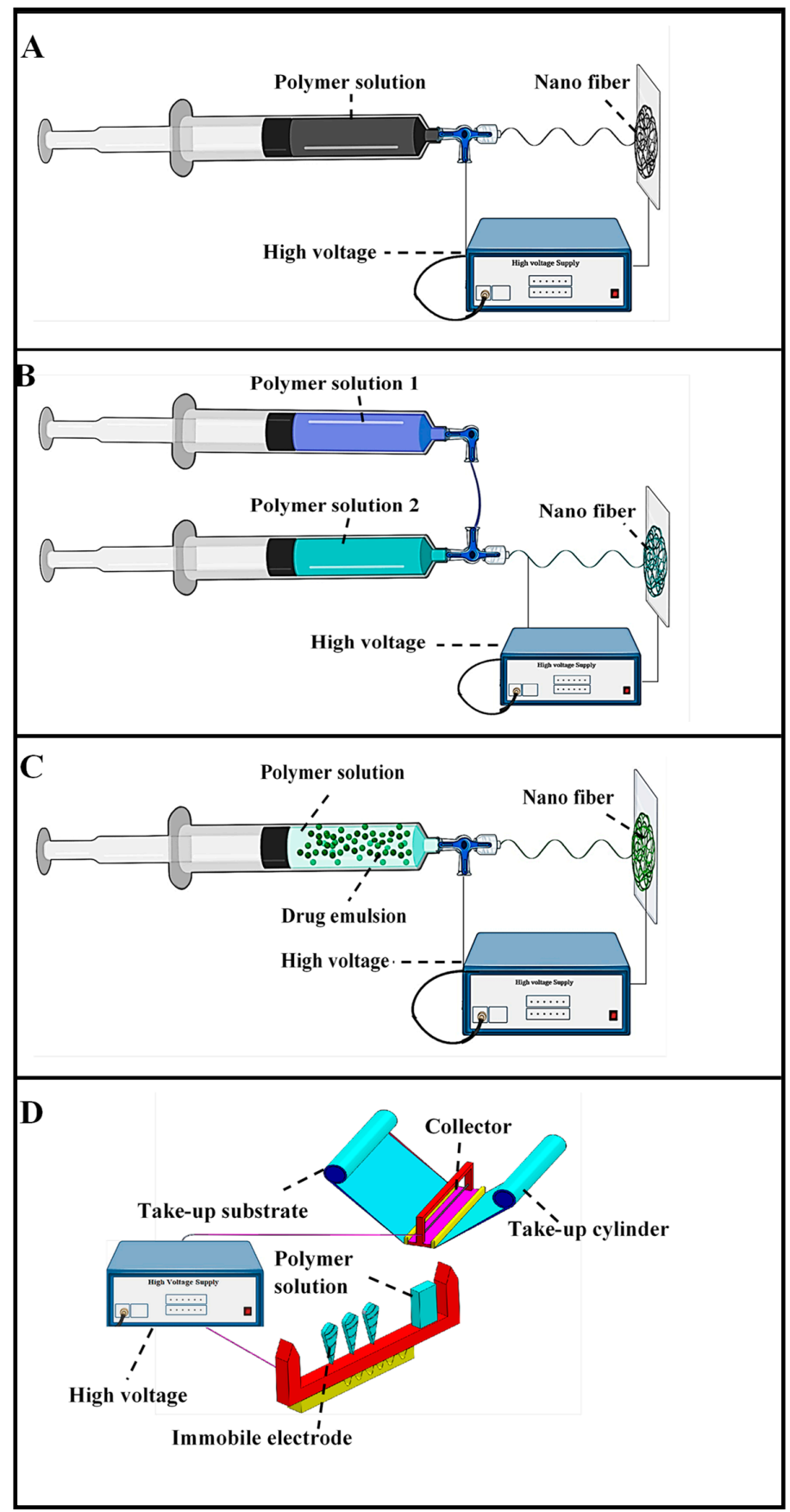

Figure 2. Electro-spinning methodologies (A) Blend electro-spinning, (B) Coaxial electro-spinning, (C) Emulsion electro-spinning, (D) Needleless electro-spinning (adapted from Repanas et al. [75], Heydari et al. [92], Manuel et al. [104], and Ambekar et al. [126]).

\section{Drug Delivery Systems Prepared by Electro-Spinning}

A very significant feature of the drug delivery systems (DDSs) is that they might minimize the operations frequency and have a constructive influence on the patient's conformity [19]. Over the past few years, the drug delivery systems based on electro-spun fibers have received increasing attention due to the unique properties of the fibers [10]. Formulations for transdermal, oral, ocular, and parenteral delivery have been developed by research teams $[75,95,99]$. GFs and proteins have been successfully encapsulated in the blend and coaxially electro-spun nano-fibers, retaining their bioactivity at the same time [127]. Core-shell fibers composed of PCL in the shell and BSA in the core have been synthesized and by the incorporation of a secondary water-soluble polymer in the shell (PEG), the 
release kinetics of albumin could be vigorously controlled [128]. Diverse pharmacological agents including analgesics, antibiotics, anti-oxidants, and anti-cancer drugs from natural products have been encapsulated into electro-spun nano-fibers [3,11,19]. Mickova et al. fabricated liposome-loaded core-shell nano-fibers (with PVA as the core and PCL as the shell) as a promising drug delivery system with adequate maintenance of the enzymatic activity of horseradish peroxidase (HRP). Furthermore, it has been reported that the scaffolds induced the mesenchymal stem cells (MSC) proliferation, making them competent biomedical candidates for drug delivery [129]. Aiming to obtain better drug-polymer compatibility and to improve the drug activity, Peng et al. suggested the use of a drug delivery system based on a blend of polymers for the sustained release of paracetamol [130]. PCL/polyurethane (PU) and PCL electro-spun nano-fibers were examined as ketoprofen carriers for local chemotherapy and the results were promising [131]. Doxorubicin hydrochloride, an anti-cancer agent, was loaded within PLLA nano-fibers [132]. Paclitaxel and doxorubicin encapsulated into PLA nano-fibers for anti-cancer treatment exhibited different release profiles [19]. Multi-layered chitosan and hyaluronic acid nano-fibrous scaffolds were employed for delivering paclitaxel, and they proved to be capable of preventing the DU145 prostate cancer cells attachment and proliferation even at low doses [133]. As an anti-coagulant and anti-proliferative pharmaceutical agent, dipyridamole has been used for treatment of cardiovascular diseases [134]. Tubular scaffolds were prepared by electro-spinning biodegradable polyurethane urea (BPU) fibers for the sustained release of dipyridamole [135]. Tensile strains and strengths of the obtained scaffolds were comparable to human coronary artery and the release of dipyridamole over 91 days could reduce human platelet deposition and extend human blood clotting time, indicating that the dipyridamole-loaded BPU scaffolds have a potential to be used as acellular biodegradable small diameter vascular grafts (SDVGs) for vascular replacement [136]. Similar results were observed for the PCL-based coaxially electro-spun fibers for encapsulating dipyridamole fabricated by our research team [135]. Although the utilization of a drug additive including dipyridamole might be considered as lacking novelty, a deeper assessment of therapeutic developments would lead to the inference that the most capable medicines might have already been discovered [137]. With a meticulous design of a drug delivery system, the local delivery of drugs with reduced side effects can enable the use of very powerful pharmaceutical agents that were either overlooked or left out of clinical usage [138]. Ciprofloxacin hydrochloride-loaded electrospun polycarbonate urethane nanofiber prepared for wound dressing showed prolonged drug release [139]. Eudragit L100-55 nano-fibers incorporated with diclofenac sodium (DS) exhibited a $\mathrm{pH}$-dependent drug generation pattern when used for the constant release of the anti-inflammatory agent and presented a great possibility to be employed as oral colon-targeted drug release systems [140]. In addition to drugs, vitamins have been encapsulated within electro-spun nano-fibers as transdermal delivery carriers with increased agent activity, and drug delivery systems for cancer treatment showed improved tumor suppression [141]. Furthermore, mechanical characteristics of the electro-spun nano-fibers were almost similar with those of human skin and cartilage [142]. SiRNA, a bioactive macromolecule that has been used as a therapeutic agent against genetic diseases, was encapsulated into polycaprolactone (PCL) nano-fibers and displayed enhanced cellular uptake [143]. Finally, electro-spun nano-fibers have been scrutinized as anti-HIV drug carriers for preventing HIV infection [144]. One method to protect against virus diffusion is the utilization of microbicides that are capable of eradicating viruses and microbes by using drug delivery systems [145]. Electro-spun c-Cbl-associated protein (CAP)-based nano-fibers loaded with either tenofovir disoproxil fumarate or the reverse-transcriptase inhibitor TMC 125 (anti-HIV agents) were produced and displayed appealing outcomes [146]. Due to their capability of dissolution in basic environment, the CAP nano-fibers could regulate the drug release based on the $\mathrm{pH}$ of the vaginal fluids. During sexual intercourse, human semen can raise the vaginal $\mathrm{pH}$ levels above 7 , which leads to the immediate dissolution of the CAP fibers. The combination of antimicrobial properties of CAP with the anti-HIV drug agents could prevent HIV disease in vitro even in substantially minimal doses [146]. 
The possibilities of different kinds of electro-spun nano-fibers for DDSs to be employed in prohibition, diagnosis and/or treatment seem to be unrestricted, provided that the many manufacturing obstacles are removed and great clinical information is attained via extreme, great quality, and extensive investigation collaborations are formed between pharmaceutical industry and academic foundations within the area of scientific research [147,148]. Table 3 represents a summary of some of the most important applications of the drugs encapsulated within electro-spun fibers as DDSs [92,139,146,149-180].

Table 3. Summary of the drug delivery of different drugs and their biomedical applications.

\begin{tabular}{|c|c|c|c|c|}
\hline Drug & Polymer & $\begin{array}{l}\text { Electrospinning } \\
\text { Method }\end{array}$ & Application & Ref. \\
\hline Ascorbylpalmitate & PCL & Blend & Infection treatment & [149] \\
\hline Amoxicillin & PCL; PLGA & Blend & Infection treatment & {$[150,151]$} \\
\hline Ampicillin & PMMA/nylon; PCL & Blend; Co-axial & Infection treatment & {$[152,153]$} \\
\hline Berberine & Collagen/ZN & Blend & Infection treatment & [154] \\
\hline Cilostazol & PCL & Blend & $\begin{array}{l}\text { Preventing coagulation of } \\
\text { blood }\end{array}$ & [155] \\
\hline Cefazolin & Gel; PLGA & Blend & Infection treatment & {$[156,157]$} \\
\hline Cefoxitin & PLGA/PEG-b-PLA & Blend & Infection treatment & [158] \\
\hline Ciprofloxacin & PCNU; PGS/PHB & Blend; Co-axial & $\begin{array}{l}\text { Infection treatment } \\
\text { Preventing the }\end{array}$ & {$[92,139]$} \\
\hline Captopril & PLLA/PLCL/PLGA & Blend & $\begin{array}{l}\text { complications of high } \\
\text { blood pressure }\end{array}$ & [159] \\
\hline Doxorubicin & PEG/PLA & Emulsion & Cancer therapy & [160] \\
\hline Doxycycline & Span 60; PCL; SLS & Emulsion & Infection treatment & [161] \\
\hline Fusidic acid & PLGA & Blend & Infection treatment & [162] \\
\hline Gentamycin & CS, PCL & Blend; Co-axial & Infection treatment & {$[163,164]$} \\
\hline Indomethacin & ERS/ES & Blend & Reducing inflammation & [165] \\
\hline Ketoprofen & PVP & Blend & Reducing inflammation & [166] \\
\hline Lidocaine & PLLA & Co-axial & $\begin{array}{l}\text { Ventricular treatment } \\
\text { tachycardia and nerve } \\
\text { blocker }\end{array}$ & [167] \\
\hline Mefoxin & $\begin{array}{l}\text { PDLA/PLLA; } \\
\text { PLGA }\end{array}$ & Blend & Infection treatment & {$[158,168]$} \\
\hline Metronidazole & PCL & Blend & $\begin{array}{l}\text { Infection treatment in } \\
\text { periodontal diseases }\end{array}$ & [169] \\
\hline Mupirocin & PCL & Blend & Infection treatment & [170] \\
\hline Nifedipine & PLGA & Blend & $\begin{array}{l}\text { Prevent the complications } \\
\text { of high blood pressure }\end{array}$ & [171] \\
\hline Paclitaxel & PLGA & Blend & Cancer therapy & [172] \\
\hline Rifampicin & PLLA & Blend & Infection treatment & [173] \\
\hline Resveratrol & PCL & Blend & Inflammation treatment & [174] \\
\hline Simvastatin & PGS/PHB & Co-axial & Infection treatment & [92] \\
\hline Salicylic Acid & $\mathrm{CS} / \mathrm{ZN}$ & Blend & $\begin{array}{l}\text { Infection treatment and } \\
\text { reducing inflammation }\end{array}$ & [175] \\
\hline Streptomycin & PU/CA/Zein & Blend & Infection treatment & [176] \\
\hline Tetracycline & $\begin{array}{l}\text { PCl/CA/Dextran; } \\
\text { PLA/PEVA; } \\
\text { PVA/CS }\end{array}$ & Blend & Infection treatment & [177-179] \\
\hline Tenofovir & PVA; CAP & Blend; Needleless & $\begin{array}{l}\text { Treatment of viral } \\
\text { infections }\end{array}$ & {$[146,180]$} \\
\hline
\end{tabular}

CAP: cellulose acetate phthalate; PHB: poly (hydroxybutyrate; PLLA: Poly (l-lactic acid); PEVA: poly (ethylene-co-vinyl acetate; CA: Cellulose acetate; CS: Chitosan; PLCL: poly (lactic-co- $\varepsilon$-caprolactone; ERS:Eudragit RS100; ES: Eudragit S100; Gel: Gelatin; PCL: Polycaprolactone; PDLA: Poly-d-lactide; PEG: Poly (ethylene glycol); PLA: Poly (lactic acid); SLS: sodium lauryl salt; PEUU: Poly (ester urethane) urea; PCNU: Polycarbonate urethane; PLGA: Poly Lactic-co-Glycolic Acid; PGS: Poly (glycerol sebacate); PLLCL: Poly (llactic acid)-b-poly (-caprolactone); PMMA: Poly (methyl methacrylate); PU: Polyurethane; PVA: Polyvinyl alcohol; PVP: Polyvinylpyrrolidone; ZN: Zein. 


\section{In Vivo Assessment of Electro-Spun Wound Dressing}

Electro-spun nano-fibers are mainly fabricated in order to obtain a biomaterial to be used in in vivo tissue regeneration $[181,182]$. Nonetheless, the first approach to understand the interaction between the cells and substrate and also the materials biocompatibility involves in vitro models. Accordingly, cell cultures are ideal for analyzing a particular cell type in certain circumstances [183]. Consequently, the complexity of the numerous variables of in vivo investigations would be avoided $[181,182]$. In a study by Ghosal et al., electro-spun nano scale fibers were fabricated by using various polymers and also $\mathrm{TiO}_{2}$ composites for wound dressing and tissue engineering. They highlighted the significance of incorporating titanium dioxide nano-particles within or on nano-fibrous scaffolds to impart functional antimicrobial properties, and the relevance of polymer-titanium dioxide nano-composites to wound dressing, drug delivery, and tissue engineering with an emphasis on in vivo biomedical applications [184]. According to Sapru et al., the nonmulberry (Antheraea mylitta) silk protein sericin-based nano-fibrous matrices prepared by electro-spinning displayed enhanced mechanical strength and proper stability (i.e., more than four weeks) as is essential for tissue reconstruction. The sericin-based nano-fibrous matrix also enhanced antibiotic (cephalexin hydrate) delivery [185]. Additionally, they added that antibiotic-loaded nano-fibrous mats accelerated wound healing with negligible inflammation and without any symptoms of illness. The in vitro and in vivo experimentations results, according to Sapru et al., indicate the clear prospect of the prepared nano-fibrous matrices for skin tissue reconstruction [185]. In vivo studies of antibiotic-loaded nano-fibrous matrices presented augmented wound healing with negligible signs of inflammation, regeneration of the lost epidermal layer as well as hair follicles, and neovascularization [99]. Tseng et al. the studies bio-gradable poly [lactic-co-glycol acid] (PLGA) nano-fibers for sustainable vancomycin delivery to the brain tissue by using electro-spinning. Their results indicate the great possibilities of these polymeric fibers to effectively address the issues of pharmacokinetics and also pharmacodynamics and to enhance the effectiveness of the therapeutic products that are employed for cerebral infections [186]. By the examination of the in vitro and in vivo release behaviors of pharmaceuticals through the membranes, their experimental outcomes indicated that the high concentrations of vancomycin could be released by bio-gradable nano-fibers pertaining to greater than eight weeks in the cerebral cavity of rats. Additionally, better drug delivery could be achieved without causing negative adverse reactions in the brain. Based on histological examinations, moreover, no inflammation response of the brain was observed, indicating that bio-gradable nano-fibrous drug eluting membranes can be adopted for long term deliveries of different antibiotics in the cerebral cavity [186]. Core-shell polyurethane fibers were used for controlled release of growth factors and, according to in vivo studies, presented an activity comparable to fresh GFs [187]. In another study, hyaluronic acid (HA) nano-fiber was electro-spun and a sterilized HA nano-fiber wound dressing was prepared and compared with four other wound dressings. The in vivo results indicated that the sterilized HA nano-fiber wound dressing was the greatest kind of dressing among other types of dressings [188]. Over the last few years, electro-spun nano-fibers have received the focal attention of many in vivo studies on biomedical applications including wound dressing by different drugs. Electro-spun PVA with phenytoin sodium nano-fibers have been utilized for wound healing purposes and the in vivo results indicated a 90\% wound healing in two week [189]. Another researcher reported the PCL nano-fiber embedded with nano-silver in order to improve the wound healing rate and based on the in vivo test results, infection was properly controlled [190]. The PCL nano-fiber with carbon nano-dots (CND) showed in vivo wound recovery and full thickness wound healing in 14 days [191]. PCL Europium hydroxide nano-rods (EHNs) displayed good wound healing properties in the rat model [192]. PCL with $\mathrm{ZnO}$ showed $85 \%$ wound healing in in vivo situations in 25 days [193]. In the case of CS/PEO nanofibers the $87 \%$ wound healing during 10 days and CS/PEO/1wt $\%$ cefazolin nano-fibers shows $99 \%$ wound healing in the same days [194]. In another in vivo test, the PLGA nano-fiber showed skin tissue regeneration [195]. The PCL/gelatin nano-fibers contain in metronidazole (MNA) demonstrated an in vivo good result in 7 days [196]. PCL/gelatin 6-aminopenicillanic acid (APA) with gold nanoparticles is another electro-spun nano fiber with an 
outstanding wound healing capacity in in vivo conditions [197]. The polyurethane/keratin/AgNP nanofiber also revealed good in vivo results in wound healing [198]. The in vivo wound healing process: (a) Hemostasis stage (b) Inflammation stage (c) Proliferation stage (d) Remodeling stage by electro-spinning wound dressing as shown in Figure 3 [199].

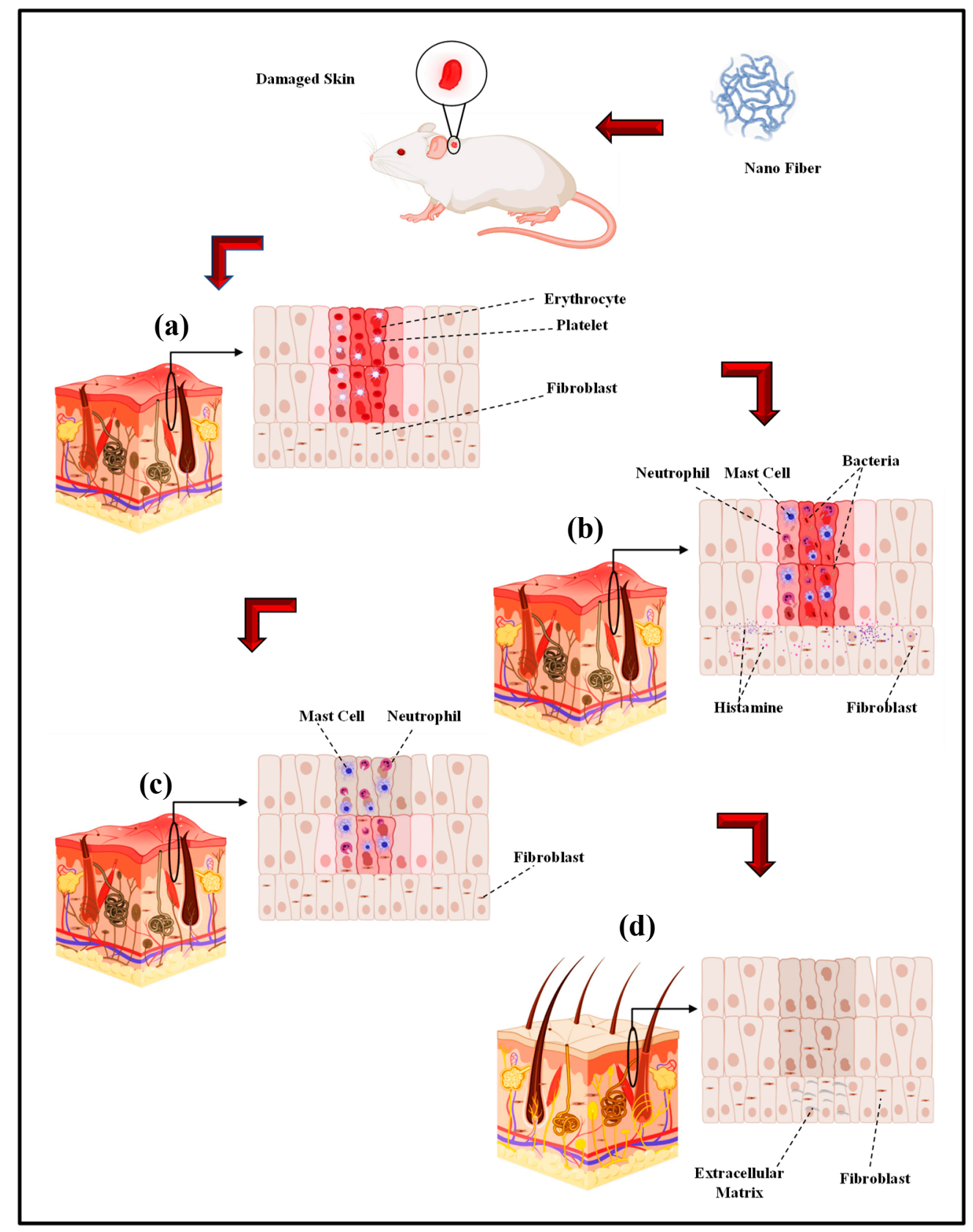

Figure 3. The in vivo wound healing process ((a) Hemostasis stage (b) Inflammation stage (c) Proliferation stage (d) Remodeling stage) by electro-spinning wound dressing (adapted from Farokhi et al. [199]).

\section{Summary and Future Road Maps}

Nowadays, nano-fiber technology advances permit the fabrication of nano-fibers from a wide range of materials including natural and synthetic polymers [200-213], ceramics, metals, as well as inorganic/inorganic or organic/inorganic composite systems [214-220]. A unique combination of properties such as the conductivity of metallic dopants accompanied by the flexibility of polymers can 
be obtained by a combination of various materials. In this area, the use or incorporation of functional nano-fibers will open new horizons of application for nano-fibrous materials. Presently, many attempts have been made to enhance the nano-fibers properties by developing different fabrication methods. Electro-spinning has the exceptional capability of generating nano-fibers by the use of different materials in different fibrous assemblies. This method has been very interesting for academic and industrial applications as it has a relatively simple setup and a high production rate. Several electrospinning methods have been developed to overcome the main limitations of the standard electrospinning method: low productivity (e.g., needleless electrospinning) and the requirement of organic solvents. These new methods also add new functions, such as controlling nanofiber morphology, compositing, electrospinning of low conductivity polymers and high molecular weight polymers [75].

In brief, electro-spun fibers are competent biomedical candidates, particularly for drug delivery purposes. Electro-spinning is usually effortlessly tuned and employed in a commercial scale to fabricate scaffolds and wound dressings pertaining to clinical purposes. Of course, there is still a lot to understand regarding the features and the usages of the electro-spun nano-fibers. This technology has been found promising in drug delivery and regenerative medicine. While antibiotic drugs and inorganic antimicrobial agents are commonly used for controlling infections, they show more acute side effects like cytotoxicity. Due to toxicity and harmful effects of the previous antibiotic medicines, researchers have been trying to find new antimicrobial agents instead of the previous ones. On the other hand, herbal medicine features antimicrobial and antioxidant antimicrobial activity and low price [221]. Herbal medicine can show positive effects on wound healing [222-224]. It is also worth noting that herbal extracts have attracted wide attention, thanks to their affordable cost and minimal negative effects compared to the antibiotic drugs. A blend of herbal extracts with electro-spun nano-fibers is certainly appealing in the field of wound dressing. In particular, these compound extracts have the ability to enhance the wound healing rate and to elevate skin regeneration. Moreover, they have the capability of hydroxyproline formation, cell adhesion, and growth attachment. Therefore, the electro-spun nano-fibers encapsulating herbal medicine have created a new interesting field in all sciences due to their unique properties. These materials can be replaced by antibiotic drugs and other antimicrobial agents like metal and metal oxide nanoparticles in electro-spun nano-fiber wound dressing. The application of these drugs has already resulted in the development of new practical productions. Considering the unquestionable role of bio-application in human life, these new fields in biomedical industry are increasingly welcomed. However, designing a new affordable and applicable system for large-scale production will not only open up a new field of study, but will also meet expanding human needs.

Author Contributions: Conceptualization, supervision, formal analysis, writing-review and editing, H.R.B.-R., A.Z.K., H.G. and A.F.I.; writing—review and editing, H.N.; writing—original draft preparation, methodology, formal analysis, S.P.; supervision, writing-review and editing, funding acquisition, F.B. All authors have read and agreed to the published version of the manuscript.

Funding: This research received no external funding.

Acknowledgments: The authors would like to thank the University Teknologi Malaysia (UTM) and Norwegian University of Science and Technology, Islamic Azad University, Najafabad and Isfahan University of Medical Sciences for providing the facilities of this research.

Conflicts of Interest: The authors declare that they have no competing/financial conflict of interests in this paper.

\section{References}

1. Barhoum, A.; Pal, K.; Rahier, H.; Uludag, H.; Kim, I.S.; Bechelany, M. Nanofibers as new-generation materials: From spinning and nano-spinning fabrication techniques to emerging applications. Appl. Mater. Today 2019, 17, 1-35. [CrossRef]

2. Huang, Z.-M.; Zhang, Y.-Z.; Kotaki, M.; Ramakrishna, S. A review on polymer nanofibers by electrospinning and their applications in nanocomposites. Compos. Sci. Technol. 2003, 63, 2223-2253. [CrossRef] 
3. Yoo, H.S.; Kim, T.G.; Park, T.G. Surface-functionalized electrospun nanofibers for tissue engineering and drug delivery. Adv. Drug Deliv. Rev. 2009, 61, 1033-1042. [CrossRef] [PubMed]

4. Li, D.; McCann, J.T.; Xia, Y. Use of electrospinning to directly fabricate hollow nanofibers with functionalized inner and outer surfaces. Small 2005, 1, 83-86.

5. Nayak, R.; Padhye, R.; Louis Kyratzis, I.; Truong, Y.B.; Arnold, L. Recent advances in nanofibre fabrication techniques. Text. Res. J. 2012, 82, 129-147. [CrossRef]

6. Bakhsheshi-Rad, H.R.; Chen, X.; Ismail, A.F.; Aziz, M.; Abdolahi, E.; Mahmoodiyan, F. Improved antibacterial properties of an $\mathrm{Mg}-\mathrm{Zn}-\mathrm{Ca}$ alloy coated with chitosan nanofibers incorporating silver sulfadiazine multiwall carbon nanotubes for bone implants. Polym. Adv. Technol. 2019, 30, 1333-1339. [CrossRef]

7. Lee, H.; Watanabe, K.; Kim, M.; Gopiraman, M.; Song, K.-H.; Lee, J.S.; Kim, I.S. Handspinning enabled highly concentrated carbon nanotubes with controlled orientation in nanofibers. Sci. Rep. 2016, 6, 37590. [CrossRef]

8. Lee, H.; Phan, D.N.; Kim, M.; Sohn, D.; Oh, S.G.; Kim, S.H.; Kim, I.S. The chemical deposition method for the decoration of palladium particles on carbon nanofibers with rapid conductivity changes. Nanomaterials 2016, 6, 226. [CrossRef]

9. Bakhsheshi-Rad, H.R.; Ismail, A.F.; Aziz, M.; Akbari, M.; Hadisi, Z.; Omidi, M.; Chen, X. Development of the PVA/CS nanofibers containing silk protein sericin as a wound dressing: In vitro and in vivo assessment. Int. J. Biol. Macromol. 2020, 149, 513-521. [CrossRef]

10. Kharaziha, M.; Nikkhah, M.; Shin, S.R.; Annabi, N.; Masoumi, N.; Gaharwar, A.K.; Camci-Unal, G.; Khademhosseini, A. PGS: Gelatin nanofibrous scaffolds with tunable mechanical and structural properties for engineering cardiac tissues. Biomaterials 2013, 34, 6355-6366. [CrossRef]

11. Hadisi, Z.; Farokhi, M.; Bakhsheshi-Rad, H.R.; Jahanshahi, M.; Hasanpour, S.; Pagan, E.; Dolatshahi-Pirouz, A.; Zhang, Y.S.; Kundu, S.C.; Akbari, M. Hyaluronic Acid (HA)-based Silk Fibroin/Zinc oxide core-shell electrospun dressing for burn wound management. Macromol. Biosci. 2020, 19, 1900328. [CrossRef] [PubMed]

12. Bakhsheshi-Rad, H.R.; Akbari, M.; Ismail, A.F.; Aziz, M.; Hadisi, Z.; Pagan, E.; Daroonparvar, M.; Chen, X. Coating biodegradable magnesium alloys with electrospun poly-L-lactic acid-akermanite-doxycycline nanofibers for enhanced biocompatibility, antibacterial activity, and corrosion resistance. Surf. Coat. Technol. 2019, 377, 124898. [CrossRef]

13. Szentivanyi, A.L.; Zernetsch, H.; Menzel, H.; Glasmacher, B. A review of developments in electrospinning technology: New opportunities for the design of artificial tissue structures. Int. J. Artif. Organs 2011, 34, 986-997. [CrossRef] [PubMed]

14. Sun, B.; Long, Y.Z.; Zhang, H.D.; Li, M.M.; Duvail, J.L.; Jiang, X.Y.; Yin, H.L. Advances in three-dimensional nanofibrous macrostructures via electrospinning. Prog. Polym. 2014, 39, 862-890. [CrossRef]

15. Bakhsheshi-Rad, H.R.; Ismail, A.F.; Aziz, M.; Hadisi, Z.; Omidi, M.; Chen, X. Antibacterial activity and corrosion resistance of $\mathrm{Ta}_{2} \mathrm{O}_{5}$ thin film and electrospun PCL/MgO-Ag nanofiber coatings on biodegradable Mg alloy implants. Ceram. Int. 2019, 45, 11883-11892. [CrossRef]

16. Sedghi, R.; Shaabani, A. Electrospun biocompatible core/shell polymerfree core structure nanofibers with superior antimicrobial potency against multi drug resistance organisms. Polymer 2016, 101, 151-157. [CrossRef]

17. Baek, J.; Lee, E.; Lotz, M.K.; D D’Lima, D. Bioactive proteins delivery through core-shell nanofibers for meniscal tissue regeneration. Nanomedicine 2020, 23, 102090. [CrossRef]

18. Gopinathan, J.; Indumathi, B.; Thomas, S.; Bhattacharyya, A. Morphology and hydroscopic properties of acrylic/thermoplastic polyurethane core-shell electrospun micro/nano fibrous mats with tunable porosity. RSC Adv. 2016, 6, 54286-54292.

19. Sill, T.J.; von Recum, H.A. Electrospinning: Applications in drug delivery and tissue engineering. Biomaterials 2008, 29, 1989-2006. [CrossRef]

20. Xu, B.; Rollo, B.; Stamp, L.A.; Zhang, D.; Fang, X.; Newgreen, D.F.; Chen, Q. Non-linear elasticity of core/shell spun PGS/PLLA fibres and their effect on cell proliferation. Biomaterials 2013, 34, 6306-6317. [CrossRef]

21. Miguel, S.P.; Figueira, D.R.; Simões, D.; Ribeiro, M.P.; Coutinho, P.; Ferreira, P.; Correia, I.J. Electrospun polymeric nanofibres as wound dressings: A review. Colloids Surf. 2018, 169, 60-71. [CrossRef] [PubMed]

22. Anindyajati, A.; Boughton, P.; Ruys, A.J. Modelling and optimization of Polycaprolactone ultrafine-fibres electrospinning process using response surface methodology. Materials 2018, 11, 441. [CrossRef] 
23. Mokhena, T.C.; Mochane, M.J.; Mtibe, A.; John, M.J.; Sadiku, E.R.; Sefadi, J.S. Electrospun alginate nanofibers toward various applications: A review. Materials 2020, 13, 934. [CrossRef] [PubMed]

24. Alexander, F.A., Jr.; Johnson, L.; Williams, K.; Packer, K. A parameter study for 3d-printing organized nanofibrous collagen scaffolds using direct-write electrospinning. Materials 2019, 12, 4131. [CrossRef] [PubMed]

25. Serbezeanu, D.; Vlad-Bubulac, T.; Rusu, D.; Grădișteanu Pircalabioru, G.; Samoilă, I.; Dinescu, S.; Aflori, M. Functional polyimide-based electrospun fibers for biomedical application. Materials 2019, 12, 3201. [CrossRef] [PubMed]

26. Şelaru, A.; Drăgușin, D.-M.; Olăreț, E.; Serafim, A.; Steinmüller-Nethl, D.; Vasile, E.; Iovu, H.; Stancu, I.C.; Costache, M.; Dinescu, S. Fabrication and biocompatibility evaluation of nanodiamonds-gelatin electrospun materials designed for prospective tissue regeneration applications. Materials 2019, 12, 2933. [CrossRef]

27. Liguori, A.; Uranga, J.; Panzavolta, S.; Guerrero, P.; de la Caba, K.; Focarete, M.L. Electrospinning of fish gelatin solution containing citric acid: An environmentally friendly approach to prepare crosslinked gelatin fibers. Materials 2019, 12, 2808. [CrossRef]

28. Paduraru, A.; Ghitulica, C.; Trusca, R.; Surdu, V.A.; Neacsu, I.A.; Holban, A.M.; Birca, A.C.; Iordache, F.; Vasile, B.S. Antimicrobial wound dressings as potential materials for skin tissue regeneration. Materials 2019, 12, 1859. [CrossRef]

29. Bakhsheshi-Rad, H.R.; Hadisi, Z.; Hamzah, E.; Ismail, A.F.; Aziz, M.; Kashefian, M. Drug delivery and cytocompatibility of ciprofloxacin loaded gelatin nanofibers-coated Mg alloy. Mater. Lett. 2017, 207, 179-182. [CrossRef]

30. Koosha, M.; Raoufi, M.; Moravvej, H. One-pot reactive electrospinning of chitosan/PVA hydrogel nanofibers reinforced by halloysite nanotubes with enhanced fibroblast cell attachment for skin tissue regeneration. Colloids Surf. B 2019, 179, 270-279. [CrossRef]

31. Wu, T.; Ding, M.; Shi, C.; Qiao, Y.; Wang, P.; Qiao, R.; Wang, X.; Zhong, J. Resorbable polymer electrospun nanofibers: History, shapes and application for tissue engineering. Chin. Chem. Lett. 2020, 31, 617-625. [CrossRef]

32. Javier, G.G.; Esther, G.C.; Magan, N.; Rahatekar, S.S. Electrospinning Alginate/Polyethylene oxide and curcumin composite nanofibers. Mater. Lett. 2020, 127662. [CrossRef]

33. Buzgo, M.; Mickova, A.; Rampichova, M.; Doupnik, M. Blend electrospinning, coaxial electrospinning, and emulsion electrospinning techniques. In Core-Shell Nanostructures for Drug Delivery and Theranostics: Challenges, Strategies and Prospects for Novel Carrier Systems, 1st ed.; Focarete, M.L., Tampieri, A., Eds.; Woodhead Publishing: Cambridge, UK, 2018; pp. 325-347.

34. Alharbi, H.F.; Luqman, M.; Khalil, K.A.; Elnakady, Y.A.; Abd-Elkader, O.H.; Rady, A.M.; Alharthi, N.H.; Karim, M.R. Fabrication of core-shell structured nanofibers of poly (lactic acid) and poly (vinyl alcohol) by coaxial electrospinning for tissue engineering. Eur. Polym. J. 2018, 1, 483-491. [CrossRef]

35. Grande, S.; Cools, P.; Asadian, M.; Van Guyse, J.; Onyshchenko, I.; Declercq, H.; Morent, R.; Hoogenboom, R.; De Geyter, N. Fabrication of PEOT/PBT nanofibers by atmospheric pressure plasma jet treatment of electrospinning solutions for tissue engineering. Macromol. Biosci. 2018, 18, 1800309. [CrossRef]

36. Mwiiri, F.K.; Daniels, R. Electrospun nanofibers for biomedical applications. In Delivery of Drugs; Elsevier: Amsterdam, The Netherlands, 2020; pp. 53-74.

37. Nirwan, V.P.; Al-Kattan, A.; Fahmi, A.; Kabashin, A.V. Fabrication of stable nanofiber matrices for tissue engineering via electrospinning of bare laser-synthesized au nanoparticles in solutions of high molecular weight Chitosan. J. Nanomater. 2019, 9, 1058. [CrossRef]

38. Aldemir Dikici, B.; Dikici, S.; Reilly, G.C.; MacNeil, S.; Claeyssens, F. A novel bilayer Polycaprolactone membrane for guided bone regeneration: Combining electrospinning and emulsion templating. Materials 2019, 12, 2643. [CrossRef]

39. Ibrahim, A.; Alomari, S. Different methods for nanofiber design and fabrication. Handb. Nanofibers 2018, 1-46. [CrossRef]

40. Van der Schueren, L.; De Schoenmaker, B.; Kalaoglu, Ö.I.; De Clerck, K. An alternative solvent system for the steady state electrospinning of polycaprolactone. Eur. Polym. J. 2011, 47, 1256-1263. [CrossRef]

41. Mori da Cunha, M.G.M.C.; Hympanova, L.; Rynkevic, R.; Mes, T.; Bosman, A.W.; Deprest, J. Biomechanical Behaviour and Biocompatibility of Ureidopyrimidinone-Polycarbonate Electrospun and Polypropylene Meshes in a Hernia Repair in Rabbits. Materials 2019, 12, 1174. [CrossRef] 
42. Casasola, R.; Thomas, N.L.; Trybala, A.; Georgiadou, S. Electrospun poly lactic acid (PLA) fibres: Effect of different solvent systems on fibre morphology and diameter. Polymer 2014, 55, 4728-4737. [CrossRef]

43. He, C.L.; Huang, Z.M.; Han, X.J.; Liu, L.; Zhang, H.S.; Chen, L.S. Coaxial electrospun poly (L-lactic acid) ultrafine fibers for sustained drug delivery. J. Macromol. Sci. B 2006, 45, 515-524. [CrossRef]

44. Geng, X.; Kwon, O.; Jang, J. Electrospinning of chitosan dissolved in concentrated acetic acid solution. Biomaterials 2005, 26, 5427-5432. [CrossRef] [PubMed]

45. Jin, H.J.; Chen, J.; Karageorgiou, V.; Altman, G.H.; Kaplan, D.L. Human bone marrow stromal cell responses on electrospun silk fibroin mats. Biomaterials 2004, 25, 1039-1047. [CrossRef]

46. Yang, L.; Fitie, C.F.; van der Werf, K.O.; Bennink, M.L.; Dijkstra, P.J.; Feijen, J. Mechanical properties of single electrospun collagen type I fibers. Biomaterials 2008, 29, 955-962. [CrossRef] [PubMed]

47. Li, J.; He, A.; Han, C.C.; Fang, D.; Hsiao, B.S.; Chu, B. Electrospinning of hyaluronic acid (HA) and HA/gelatin blends. Macromol. Rapid. Commun. 2006, 27, 114-120. [CrossRef]

48. Majdi, A.; Biazar, E.; Heidari, S. Fabrication and comparison of electro-spun poly hydroxy butyrate valrate nanofiber and normal film and its cellular study. Orient. J. Chem. 2011, 27, 523-528.

49. Angel, N.; Guo, L.; Yan, F.; Wang, H.; Kong, L. Effect of processing parameters on the electrospinning of cellulose acetate studied by response surface methodology. J. Sci. Food Agric. 2020, 2, 100015. [CrossRef]

50. Jeffries, E.M.; Allen, R.A.; Gao, J.; Pesce, M.; Wang, Y. Highly elastic and suturable electrospun poly (glycerol sebacate) fibrous scaffolds. Acta Biomater. 2015, 18, 30-39. [CrossRef]

51. Li, M.; Mondrinos, M.J.; Chen, X.; Gandhi, M.R.; Ko, F.K.; Lelkes, P.I. Co-electrospun poly (lactide-co-glycolide), gelatin, and elastin blends for tissue engineering scaffolds. J. Biomed. Mater. Res. A 2006, 79, 963-973. [CrossRef]

52. Zhang, Y.Z.; Venugopal, J.; Huang, Z.-M.; Lim, C.T.; Ramakrishna, S. Crosslinking of the electrospun gelatin nanofibers. Polymer 2006, 47, 2911-2917. [CrossRef]

53. Torres-Giner, S.; Echegoyen, Y.; Teruel-Juanes, R.; Badia, J.D.; Ribes-Greus, A.; Lagaron, J.M. Electrospun poly (ethylene-co-vinyl alcohol)/graphene nanoplatelets composites of interest in intelligent food packaging applications. Nanomaterials 2018, 8, 745. [CrossRef] [PubMed]

54. Min, B.M.; Lee, S.W.; Lim, J.N.; You, Y.; Lee, T.S.; Kang, P.H.; Park, W.H. Chitin and chitosan nanofibers: Electrospinning of chitin and deacetylation of chitin nanofibers. Polymer 2004, 45, 7137-7142. [CrossRef]

55. Yeo, I.S.; Oh, J.E.; Jeong, L.; Lee, T.S.; Lee, S.J.; Park, W.H.; Min, B.M. Collagen-based biomimetic nanofibrous scaffolds: Preparation and characterization of collagen/silk fibroin bicomponent nanofibrous structures. Biomacromolecules 2008, 9, 1106-1116. [CrossRef] [PubMed]

56. Kim, J.H.; Jang, J.; Jeong, Y.H.; Ko, T.J.; Cho, D.W. Fabrication of a nanofibrous mat with a human skin pattern. Langmuir 2015, 31, 424-431. [CrossRef]

57. Ishii, D.; Ying, T.H.; Mahara, A.; Murakami, S.; Yamaoka, T.; Lee, W.K.; Iwata, T. In vivo tissue response and degradation behavior of PLLA and stereocomplexed PLA nanofibers. Biomacromolecules 2009, 10, 237-242. [CrossRef] [PubMed]

58. Levengood, S.L.; Erickson, A.E.; Chang, F.C.; Zhang, M. Chitosan-poly (caprolactone) nanofibers for skin repair. J. Mater. Chem. B 2017, 5, 1822-1833. [CrossRef] [PubMed]

59. Aydogdu, M.O.; Altun, E.; Crabbe-Mann, M.; Brako, F.; Koc, F.; Ozen, G.; Kuruca, S.E.; Edirisinghe, U.; Luo, C.J.; Gunduz, O.; et al. Cellular interactions with bacterial cellulose: Polycaprolactone nanofibrous scaffolds produced by a portable electrohydrodynamic gun for point-of-need wound dressing. Int. Wound J. 2018, 15, 789-797. [CrossRef]

60. Zhou, Y.; Yang, D.; Chen, X.; Xu, Q.; Lu, F.; Nie, J. Electrospun water-soluble carboxyethyl chitosan/poly (vinyl alcohol) nanofibrous membrane as potential wound dressing for skin regeneration. Biomacromolecules 2008, 9, 349-354. [CrossRef]

61. Pakravan, M.; Heuzey, M.C.; Ajji, A. A fundamental study of chitosan/PEO electrospinning. Polymer 2011, 52, 4813-4824. [CrossRef]

62. Jiang, H.; Hu, Y.; Li, Y.; Zhao, P.; Zhu, K.; Chen, W. A facile technique to prepare biodegradable coaxial electrospun nanofibers for controlled release of bioactive agents. J. Control. Release 2005, 108, 237-243. [CrossRef]

63. Torres-Giner, S.; Martinez-Abad, A.; Gimeno-Alcañiz, J.V.; Ocio, M.J.; Lagaron, J.M. Controlled delivery of gentamicin antibiotic from bioactive electrospun polylactide-based ultrathin fibers. Adv. Eng. Mater. 2012, 14, 112-122. [CrossRef] 
64. Nguyen, T.T.; Chung, O.H.; Park, J.S. Coaxial electrospun poly (lactic acid)/chitosan (core/shell) composite nanofibers and their antibacterial activity. Carbohydr. Polym. 2011, 86, 1799-1806. [CrossRef]

65. Tchemtchoua, V.T.; Atanasova, G.; Aqil, A.; Filée, P.; Garbacki, N.; Vanhooteghem, O.; Deroanne, C.; Noël, A.; Jérome, C.; Nusgens, B.; et al. Development of a chitosan nanofibrillar scaffold for skin repair and regeneration. Biomacromolecules 2011, 12, 3194-3204. [CrossRef] [PubMed]

66. Xing, Z.C.; Chae, W.P.; Baek, J.Y.; Choi, M.J.; Jung, Y.; Kang, I.K. In vitro assessment of antibacterial activity and cytocompatibility of silver-containing PHBV nanofibrous scaffolds for tissue engineering. Biomacromolecules 2010, 11, 1248-1253. [CrossRef]

67. Ghaffari-Bohlouli, P.; Hamidzadeh, F.; Zahedi, P.; Shahrousvand, M.; Fallah-Darrehchi, M. Antibacterial nanofibers based on poly (l-lactide-co-d, l-lactide) and poly (vinyl alcohol) used in wound dressings potentially: A comparison between hybrid and blend properties. J. Biomater. Sci. Polym. Ed. 2020, 31, 219-243. [CrossRef]

68. Gao, W.; Sun, L.; Fu, X.; Lin, Z.; Xie, W.; Zhang, W.; Zhao, F.; Chen, X. Enhanced diabetic wound healing by electrospun core-sheath fibers loaded with dimethyloxalylglycine. J. Mater. Chem. B 2018, 6, $277-288$. [CrossRef]

69. Kandhasamy, S.; Perumal, S.; Madhan, B.; Umamaheswari, N.; Banday, J.A.; Perumal, P.T.; Santhanakrishnan, V.P. Synthesis and fabrication of collagen-coated ostholamide electrospun nanofiber scaffold for wound healing. ACS Appl. Mater. Interfaces 2017, 9, 8556-8568. [CrossRef]

70. Datta, S.; Rameshbabu, A.P.; Bankoti, K.; Maity, P.P.; Das, D.; Pal, S.; Roy, S.; Sen, R.; Dhara, S. Oleoyl-chitosan-based nanofiber mats impregnated with amniotic membrane derived stem cells for accelerated full-thickness excisional wound healing. Acs Biomater. Sci. Eng. 2017, 3, 1738-1749. [CrossRef]

71. Ojha, S.S.; Stevens, D.R.; Hoffman, T.J.; Stano, K.; Klossner, R.; Scott, M.C.; Krause, W.; Clarke, L.I.; Gorga, R.E. Fabrication and characterization of electrospun chitosan nanofibers formed via templating with polyethylene oxide. Biomacromolecules 2008, 9, 2523-2529. [CrossRef]

72. Chhabra, H.; Deshpande, R.; Kanitkar, M.; Jaiswal, A.; Kale, V.P.; Bellare, J.R. A nano zinc oxide doped electrospun scaffold improves wound healing in a rodent model. RSC Adv. 2016, 6, 1428-1439. [CrossRef]

73. Ren, X.; Han, Y.; Wang, J.; Jiang, Y.; Yi, Z.; Xu, H.; Ke, Q. An aligned porous electrospun fibrous membrane with controlled drug delivery-An efficient strategy to accelerate diabetic wound healing with improved angiogenesis. Acta Biomater. 2018, 70, 140-153. [CrossRef] [PubMed]

74. Worley, B.V.; Soto, R.J.; Kinsley, P.C.; Schoenfisch, M.H. Active release of nitric oxide-releasing dendrimers from electrospun polyurethane fibers. ACS Biomater. 2016, 2, 426-437. [CrossRef] [PubMed]

75. Repanas, A.; Andriopoulou, S.; Glasmacher, B. The significance of electrospinning as a method to create fibrous scaffolds for biomedical engineering and drug delivery applications. J. Drug Deliv. Sci. Technol. 2016, 31, 137-146. [CrossRef]

76. Wang, J.; Windbergs, M. Functional electrospun fibers for the treatment of human skin wounds. Eur. J. Pharm. Biopharm. 2017, 119, 283-299. [CrossRef]

77. Zhao, R.; Liang, H.; Clarke, E.; Jackson, C.; Xue, M. Inflammation in chronic wounds. Int. J. Mol. Sci. 2016, 17, 2085. [CrossRef]

78. Xianfeng, W.; Gang Sun, B.D.; Wang, M.; Yu, J. Electro-spinning/netting: A strategy for the fabrication of three-dimensional polymer nano-fiber/nets. Prog. Mater. Sci. 2013, 58, 1173-1243.

79. Wang, B.; Cai, Q.; Zhang, S.; Yang, X.; Deng, X. The effect of poly (L-lactic acid) nanofiber orientation on osteogenic responses of human osteoblast-like MG63 cells. J. Mech. Behav. Biomed. Mater. 2011, 4, 600-609. [CrossRef]

80. Wang, X.; Yu, J.; Sun, G.; Ding, B. Electrospun nanofibrous materials: A versatile medium for effective oil/water separation. Mater. Today 2016, 19, 403-414. [CrossRef]

81. Goh, Y.F.; Shakir, I.; Hussain, R. Electrospun fibers for tissue engineering, drug delivery, and wound dressing. J. Mater. Sci. 2013, 48, 3027-3054. [CrossRef]

82. Zhang, J.G.; Mo, X.M. Current research on electrospinning of silk fibroin and its blends with natural and synthetic biodegradable polymers. Front. Mater. Sci. 2013, 7, 129-142. [CrossRef]

83. Kanmaz, D.; Toprakci, H.A.; Olmez, H.; Toprakci, O. Electrospun polylactic acid based nanofibers for biomedical applications. Mater. Sci. Res. India 2018, 15, 224-240. [CrossRef]

84. Sabir, M.I.; Xu, X.; Li, L. A review on biodegradable polymeric materials for bone tissue engineering applications. J. Mater. Sci. 2009, 44, 5713-5724. [CrossRef] 
85. Rieger, K.A.; Thyagarajan, R.; Hoen, M.E.; Yeung, H.F.; Ford, D.M.; Schiffman, J.D. Transport of microorganisms into cellulose nanofiber mats. RSC Adv. 2016, 6, 24438-24445. [CrossRef]

86. Kurniawan, A.; Wang, M.J. Gold nanoparticles-decorated electrospun poly (N-vinyl-2-pyrrolidone) nanofibers with tunable size and coverage density for nanomolar detection of single and binary component dyes by surface-enhanced raman spectroscopy. Nanotechnology 2017, 28, 355703. [CrossRef]

87. Li, W.; Li, X.; Chen, Y.; Li, X.; Deng, H.; Wang, T.; Huang, R.; Fan, G. Poly (vinyl alcohol)/sodium alginate/layered silicate based nanofibrous mats for bacterial inhibition. Carbohydr. Polym. 2013, 92, 2232-2238. [CrossRef]

88. Chouhan, D.; Chakraborty, B.; Nandi, S.K.; Mandal, B.B. Role of non-mulberry silk fibroin in deposition and regulation of extracellular matrix towards accelerated wound healing. Acta Biomater. 2017, 48, 157-174. [CrossRef] [PubMed]

89. Szentivanyi, A.; Chakradeo, T.; Zernetsch, H.; Glasmacher, B. Electrospun cellular microenvironments: Understanding controlled release and scaffold structure. Adv. Drug Deliv. Rev. 2011, 63, 209-220. [CrossRef]

90. Choi, J.S.; Choi, S.H.; Yoo, H.S. Coaxial electrospun nanofibers for treatment of diabetic ulcers with binary release of multiple growth factors. J. Mater. Chem. 2011, 21, 5258-5267. [CrossRef]

91. Zhang, J.F.; Yang, D.Z.; Xu, F.; Zhang, Z.P.; Yin, R.X.; Nie, J. Electrospun core-shell structure nanofibers from homogeneous solution of poly(ethylene oxide)/chitosan. Macromolecules 2009, 42, 5278-5284. [CrossRef]

92. Heydari, P.; Varshosaz, J.; Zargar Kharazi, A.; Karbasi, S. Preparation and evaluation of poly glycerol sebacate/poly hydroxy butyrate core-shell electrospun nanofibers with sequentially release of ciprofloxacin and simvastatin in wound dressings. Polym. Adv. Technol. 2018, 29, 1795-1803. [CrossRef]

93. Yan, E.; Fan, Y.; Sun, Z.; Gao, J.; Hao, X.; Pei, S.; Wang, C.; Sun, L.; Zhang, D. Biocompatible core-shell electrospun nanofibers as potential application for chemotherapy against ovary cancer. Mater. Sci. Eng. C 2014, 41, 217-223. [CrossRef] [PubMed]

94. Surucu, S.; Sasmazel, H.T. Development of core-shell coaxially electrospun composite PCL/chitosan scaffolds. Int. J. Biol. Macromol. 2016, 92, 321-328. [CrossRef] [PubMed]

95. Chakraborty, S.; Liao, I.-C.; Adler, A.; Leong, K.W. Electrohydrodynamics: A facile technique to fabricate drug delivery systems. Adv. Drug Deliv. Rev. 2009, 61, 1043-1054. [CrossRef] [PubMed]

96. Sun, D.H.; Xu, T.Y.; Liu, Y.J.; Zhang, M. Preparation of PVA/PEG phase change composite nanofibers by electrospinning. Adv. Mater. Res. 2011, 306, 37-40. [CrossRef]

97. Maleknia, L.; Dilamian, M.; Pilehrood, M.K.; Sadeghi-Aliabadi, H.; Hekmati, A.H. Preparation, process optimization and characterization of core-shell polyurethane/chitosan nanofibers as a potential platform for bioactive scaffolds. Res. Pharm. Sci. 2018, 13, 273. [CrossRef]

98. Maleki Dizaj, S.; Sharifi, S.; Jahangiri, A. Electrospun nanofibers as versatile platform in antimicrobial delivery: Current state and perspectives. Pharm. Dev. Technol. 2019, 24, 1187-1199. [CrossRef]

99. Yuan, X.; Zhang, M.; Wang, Y.; Zhao, H.; Sun, D. Using co-axial electrospray deposition to eliminate burst release of simvastatin from microparticles and to enhance induced osteogenesis. J. Biomater. Sci. Polym. Ed. 2019, 30, 355-375. [CrossRef]

100. Yang, H.S.; Shin, J.; Bhang, S.H.; Shin, J.Y.; Park, J.; Im, G.I.; Kim, C.S.; Kim, B.S. Enhanced skin wound healing by a sustained release of growth factors contained in platelet-rich plasma. Exp. Mol. Med. 2011, 43, 622-629. [CrossRef]

101. Eatemadi, A.; Daraee, H.; Zarghami, N.; Melat Yar, H.; Akbarzadeh, A. Nanofiber: Synthesis and biomedical applications. Artif. Cells Nanomed. Biotechnol. 2016, 44, 111-121. [CrossRef]

102. Brannon-Peppas, L.; Ghosn, B.; Roy, K.; Cornetta, K. Encapsulation of nucleic acids and opportunities for cancer treatment. Pharm. Res. 2007, 24, 618-627. [CrossRef]

103. Luu, Y.K.; Kim, K.; Hsiao, B.S.; Chu, B.; Hadjiargyrou, M. Development of a nanostructured DNA delivery scaffold via electrospinning of PLGA and PLA-PEG block copolymers. J. Control. Release 2003, 89, 341-353. [CrossRef]

104. Manuel, C.B.J.; Gómez Luis Jesús, V.; Medina Aracely, S. Electrospinning for drug delivery systems: Drug incorporation techniques. In Electrospinning-Material, Techniques, and Biomedical Applications, 1st ed.; Haider, S., Haider, A., Eds.; IntechOpen: London, UK, 2016; p. 141.

105. Fuller, K.; Pandit, A.; Zeugolis, D.I. The multifaceted potential of electro-spinning in regenerative medicine. Pharm. Nanotechnol. 2014, 2, 23-34. [CrossRef] 
106. Wang, Z.; Qian, Y.; Li, L.; Pan, L.; Njunge, L.W.; Dong, L.; Yang, L. Evaluation of emulsion electrospun polycaprolactone/hyaluronan/epidermal growth factor nanofibrous scaffolds for wound healing. J. Biomater. Appl. 2016, 30, 686-698. [CrossRef] [PubMed]

107. Qi, H.X.; Hu, P.; Xu, J.; Wang, A.J. Encapsulation of drug reservoirs in fibers by emulsion electrospinning: Morphology characterization and preliminary release assessment. Biomacromolecules 2006, 7, 2327-2330. [CrossRef] [PubMed]

108. Hu, J.; Prabhakaran, M.P.; Tian, L.; Ding, X.; Ramakrishna, S. Drug-loaded emulsion electrospun nanofibers: Characterization, drug release and in vitro biocompatibility. RSC Adv. 2015, 5, 100256-100267. [CrossRef]

109. Yan, S.; Xiaoqiang, L.; Shuiping, L.; Xiumei, M.; Ramakrishna, S. Controlled release of dual drugs from emulsion electrospun nanofibrous mats. Colloids Surf. B 2009, 73, 376-381. [CrossRef]

110. Xu, X.; Yang, L.; Xu, X.; Wang, X.; Chen, X.; Liang, Q.; Zeng, J.; Jing, X. Ultrafine medicated fibers electrospun from W/O emulsions. J. Control. Release 2005, 108, 33-42. [CrossRef]

111. Tian, L.; Prabhakaran, M.P.; Ding, X.; Kai, D.; Ramakrishna, S. Emulsion electrospun vascular endothelial growth factor encapsulated poly (l-lactic acid-co- $\varepsilon$-caprolactone) nanofibers for sustained release in cardiac tissue engineering. J. Mater. Sci. 2012, 47, 3272-3281. [CrossRef]

112. Chen, X.; Wang, J.; An, Q.; Li, D.; Liu, P.; Zhu, W.; Mo, X. Electrospun poly (l-lactic acid-co-e-caprolactone) fibers loaded with heparin and vascular endothelial growth factor to improve blood compatibility and endothelial progenitor cell proliferation. Colloids Surfaces B Biointerfaces 2015, 128, 106-114. [CrossRef]

113. Wang, X.; Niu, H.; Lin, T.; Wang, X. Needleless electrospinning of nanofibers with a conical wire coil. Polym. Eng. Sci. 2009, 49, 1582-1586. [CrossRef]

114. Maver, T.; Kurečič, M.; Pivec, T.; Maver, U.; Gradišnik, L.; Gašparič, P.; Kaker, B.; Bratuša, A.; Hribernik, S.; Kleinschek, K.S. Needleless electrospun carboxymethyl cellulose/polyethylene oxide mats with medicinal plant extracts for advanced wound care applications. Cellulose 2020, 1-22. [CrossRef]

115. Ng, J.-J.; Supaphol, P. Rotating-disk electrospinning: Needleless electrospinning of poly (caprolactone), poly (lactic acid) and poly (vinyl alcohol) nanofiber mats with controlled morphology. J. Polym. Res. 2018, 25, 155. [CrossRef]

116. Wang, L.; Zhang, C.; Gao, F.; Pan, G. Needleless electrospinning for scaled-up production of ultrafine chitosan hybrid nanofibers used for air filtration. RSC Adv. 2016, 6, 105988-105995. [CrossRef]

117. Grimmelsmann, N.; Homburg, S.V.; Ehrmann, A. Needleless electrospinning of pure and blended chitosan. Mater. Sci. Eng. 2017, 225, 012098. [CrossRef]

118. Wortmann, M.; Frese, N.; Sabantina, L.; Petkau, R.; Kinzel, F.; Gölzhäuser, A.; Moritzer, E.; Hüsgen, B.; Ehrmann, A. New polymers for needleless electrospinning from low-toxic solvents. Nanomaterials 2019, 9, 52. [CrossRef]

119. Dubský, M.; Kubinová, Š.; Širc, J.; Voska, L.; Zajíček, R.; Zajícová, A.; Lesný, P.; Jirkovská, A.; Michálek, J.; Munzarová, M.; et al. Nanofibers prepared by needleless electrospinning technology as scaffolds for wound healing. J. Mater. Sci. Mater. Med. 2012, 23, 931-941. [CrossRef]

120. Mamun, A. Review of possible applications of nanofibrous mats for wound dressings. Tekstilec 2019, 62, 89-100. [CrossRef]

121. Parham, S.; Wicaksono, D.H.B.; Bagherbaigi, S.; Lee, S.L.; Nur, H. Antimicrobial treatment of different metal oxide nanoparticles: A critical review. J. Chin. Chem. Soc-Taip. 2016, 63, 385-393. [CrossRef]

122. Parham, S.; Chandren, S.; Wicaksono, D.H.B.; Bagherbaigi, S.; Lee, S.L.; Yuan, L.S.; Nur, H. Textile/ $\mathrm{Al}_{2} \mathrm{O}_{3}-\mathrm{TiO}_{2}$ nanocomposite as an antimicrobial and radical scavenger wound dressing. RSC Adv. 2016, 6, 8188-8197. [CrossRef]

123. Makvandi, P.; Wang, C.-Y.; Zare, E.N.; Borzacchiello, A.; Niu, L.-N.; Tay, F.R. Metal-based nanomaterials in biomedical applications: Antimicrobial activity and cytotoxicity aspects. Adv. Funct. Mater. 2020, 1910021. [CrossRef]

124. Parham, S.; Nemati, M.; Sadir, S.; Bagherbaigi, S.; Wicaksono, D.H.B.; Nur, H. In situ synthesis of silver nanoparticles for Ag-NP/Cotton nanocomposite and its bactericidal effect. J. Chin. Chem. Soc-Taip. 2017, 64, 1286-1293. [CrossRef]

125. Parham, S.; Wicaksono, D.H.B.; Nur, H. A proposed mechanism of action of textile $/ \mathrm{Al}_{2} \mathrm{O}_{3}-\mathrm{TiO}_{2}$ bimetal oxide nanocomposite as an antimicrobial agent. J. Text. Inst. 2019, 110, 791-798. [CrossRef]

126. Ambekar, R.S.; Kandasubramanian, B. Advancements in nanofibers for wound dressing: A review. Eur. Polym. J. 2019, 117, 304-336. [CrossRef] 
127. Abrigo, M.; McArthur, S.L.; Kingshott, P. Electrospun nanofibers as dressings for chronic wound care: Advances, challenges, and future prospects. Macromol. Biosci. 2014, 14, 772-792. [CrossRef] [PubMed]

128. Jiang, H.; Hu, Y.; Zhao, P.; Li, Y.; Zhu, K. Modulation of protein release from biodegradable core-shell structured fibers prepared by coaxial electrospinning. J. Biomed. Mater. Res. B Appl. Biomater. 2006, 79B, 50-57. [CrossRef] [PubMed]

129. Mickova, A.; Buzgo, M.; Benada, O.; Rampichova, M.; Fisar, Z.; Filova, E.; Tesarova, M.; Lukas, D.; Amler, E. Core/shell nanofibers with embedded liposomes as a drug delivery system. Biomacromolecules 2012, 13, 952-962. [CrossRef] [PubMed]

130. Peng, H.; Zhou, S.; Guo, T.; Li, Y.; Li, X.; Wang, J.; Weng, J. In vitro degradation and release profiles for electrospun polymeric fibers containing paracetanol. Colloids Surf. B 2008, 66, 206-212. [CrossRef]

131. Kenawy, E.R.; Abdel-Hay, F.I.; El-Newehy, M.H.; Wnek, G.E. Processing of polymer nanofibers through electrospinning as drug delivery systems. In Nanomaterials: Risks and Benefits; Springer: Dordrecht, The Netherlands, 2009; pp. 247-263.

132. Zeng, J.; Yang, L.; Liang, Q.; Zhang, X.; Guan, H.; Xu, X.; Chen, X.; Jing, X. Influence of the drug compatibility with polymer solution on the release kinetics of electrospun fiber formulation. J. Control. Release 2005, 105, 43-51. [CrossRef]

133. Ma, G.; Liu, Y.; Peng, C.; Fang, D.; He, B.; Nie, J. Paclitaxel loaded electrospun porous nanofibers as mat potential application for chemotherapy against prostate cancer. Carbohydr. Polym. 2011, 86, 505-512. [CrossRef]

134. Awad, N.K.; Niu, H.; Ali, U.; Morsi, Y.S.; Lin, T. Electrospun fibrous scaffolds for small-diameter blood vessels: A review. Membranes 2018, 8, 15. [CrossRef]

135. Punnakitikashem, P.; Truong, D.; Menon, J.U.; Nguyen, K.T.; Hong, Y. Electrospun biodegradable elastic polyurethane scaffolds with dipyridamole release for small diameter vascular grafts. Acta Biomater. 2014, 10, 4618-4628. [CrossRef] [PubMed]

136. Repanas, A.; Glasmacher, B. Dipyridamole embedded in Polycaprolactone fibers prepared by coaxial electrospinning as a novel drug delivery system. J. Drug Deliv. Sci. Technol. 2015, 29, 132-142. [CrossRef]

137. Forbes, C.D. Secondary stroke prevention with low-dose aspirin, sustained release dipyridamole alone and in combination. ESPS Investigators. European Stroke Prevention Study. Thromb. Res. 1998, 92, 1-6. [CrossRef]

138. Han, F.; Jia, X.; Dai, D.; Yang, X.; Zhao, J.; Zhao, Y.; Fan, Y.; Yuan, X. Performance of a multilayered small-diameter vascular scaffold dual-loaded with VEGF and PDGF. Biomaterials 2013, 34, 7302-7313. [CrossRef]

139. Wright, M.E.E.; Parrag, I.C.; Yang, M.; Santerre, J.P. Electrospun polyurethane nanofiber scaffolds with ciprofloxacin oligomer versus free ciprofloxacin: Effect on drug release and cell attachment. J. Control. Release 2017, 250, 107-115. [CrossRef]

140. Zupančič, S. Core-shell nanofibers as drug-delivery systems. Acta Pharm. 2019, 69, 131-153. [CrossRef]

141. Stevanovic, M.; Uskokovic, D. Poly (lactide-co-glycolide)-based micro and nanoparticles for the controlled drug delivery of vitamins. Curr. Nanosci. 2009, 5, 1-14.

142. Font Tellado, S.; Balmayor, E.R.; Van Griensven, M. Strategies to engineer tendon/ligament- to-bone interface: Biomaterials, cells and growth factors. Adv. Drug Deliv. Rev. 2015, 94, 126-140. [CrossRef]

143. Hong, B.J.; Chipre, A.J.; Nguyen, S.-B.T. Acid-degradable polymer-caged lipoplex (PCL) platform for siRNA delivery: Facile cellular triggered release of siRNA. J. Am. Chem. Soc. 2013, 135, 17655-17658. [CrossRef]

144. Yang, D.; Niu, X.; Liu, Y.; Wang, Y.; Gu, X.; Song, L.; Zhao, R.; Ma, L.; Shao, Y.; Jiang, X. Electrospun nanofibrous membranes: A novel solid substrate for microfluidic immunoassays for HIV. Adv. Mater. 2008, 20, 4770-4775. [CrossRef]

145. Singh, A.; Rath, G.; Singh, R.; Goyal, A.K. Nanofibers: An effective tool for controlled and sustained drug delivery. Curr. Drug Deliv. 2018, 15, 155-166. [CrossRef] [PubMed]

146. Huang, C.; Soenen, S.J.; Gulck, E.-V.; Vanham, G.; Rejman, J.; Calenbergh, S.-V.; Vervaet, C.; Coenye, T.; Verstraelen, H.; Temmerman, M.; et al. Electrospun cellulose acetate phthalate fibers for semen induced anti-HIV vaginal drug delivery. Biomaterials 2012, 33, 962-969. [CrossRef] [PubMed]

147. Poveda, E.; Garrido, C.; de Mendoza, C.; Corral, A.; Cobo, J.; Gonzalez-Lahoz, J.; Soriano, V. Prevalence of etravirine (TMC-125) resistance mutations in HIV-infected patients with prior experience of non-nucleoside reverse transcriptase inhibitors. J. Antimicrob. Chemother. 2007, 60, 1409-1410. [CrossRef] [PubMed] 
148. Yu, D.G.; Branford-White, C.; Li, L.; Wu, X.M.; Zhu, L.M. The compatibility of acyclovir with polyacrylonitrile in the electrospun drug-loaded nanofibers. J. Appl. Polym. Sci. 2010, 117, 1509-1515. [CrossRef]

149. Paneva, D.; Manolova, N.; Argirova, M.; Rashkov, I. Antibacterial electrospun poly(caprolactone)/ ascorbylpalmitate nanofibrous materials. Int. J. Pharm. 2011, 416, 346-355. [CrossRef]

150. Valarezo, E.; Stanzione, M.; Tammaro, L.; Cartuche, L.; Malagón, O.; Vittoria, V. Preparation, characterization and antibacterial activity of poly ( $\varepsilon$-caprolactone) electrospun fibers loaded with amoxicillin for controlled release in biomedical applications. J. Nanosci. Nanotechnol. 2013, 13, 1717-1726. [CrossRef]

151. Sofokleous, P.; Stride, E.; Edirisinghe, M. Preparation, characterization, and release of amoxicillin from electrospun fibrous wound dressing patches. Pharm. Res. 2013, 30, 1926-1938. [CrossRef]

152. Sohrabi, A.; Shaibani, P.M.; Etayash, H.; Kaur, K.; Thundat, T. Sustained drug release and antibacterial activity of ampicillin incorporated poly (methyl methacrylate)-nylon6 core/shell nanofibers. Polymer 2013, 54, 2699-2705. [CrossRef]

153. Liu, H.; Leonas, K.K.; Zhao, Y. Antimicrobial properties and release profile of ampicillin from electrospun Poly (eepsilon;-caprolactone) nanofiber yarns. J. Eng. Fibers Fabr. 2010, 5, 10-19. [CrossRef]

154. Lin, J.; Li, C.; Li, C.; Zhao, Y.; Hu, J.; Zhang, L.-M. Co-electrospun nanofibrous membranes of collagen and zein for wound healing. ACS Appl. Mater. Interfaces 2012, 4, 1050-1057. [CrossRef]

155. Marek, R.; Anna, B.K.; Bartłomiej, M.; Marcin, J.; Barbara, M.; Emerson, L.; Lulek, J. Cilostazol-loaded Poly( $\varepsilon$-Caprolactone) electrospun drug delivery system for cardiovascular applications. Pharm. Res. 2018, $35,1-20$.

156. Rath, G.; Hussain, T.; Chauhan, G.; Garg, T.; Goyal, A.K. Development and characterization of cefazolin loaded zinc oxide nanoparticles composite gelatin nanofiber mats for postoperative surgical wounds. Mater. Sci. Eng. C 2016, 58, 242-253.

157. Katti, D.S.; Robinson, K.W.; Ko, F.K.; Laurencin, C.T. Bioresorbable nanofiber-based systems for wound healing and drug delivery: Optimization of fabrication parameters. J. Biomed. Mater. Res. B Appl. Biomater. 2004, 70, 286-296. [CrossRef]

158. Kim, K.; Luu, Y.K.; Chang, C.; Fang, D.; Hsiao, B.S.; Chu, B.; Hadjiargyrou, M. Incorporation and controlled release of a hydrophilic antibiotic using poly (lactide-co-glycolide)-based electrospun nanofibrous scaffolds. J. Control. Release 2004, 98, 47-56. [CrossRef] [PubMed]

159. Zhang, H.; Lou, S.; Williams, G.R.; Branford-White, C.; Nie, H.; Quan, J.; Zhu, L.-M. A systematic study of captopril loaded polyester fiber mats prepared by electrospinning. Int. J. Pharm. 2012, 439, 100-108. [CrossRef] [PubMed]

160. Xu, X.; Chen, X.; Ma, P.; Wang, X.; Jing, X. The release behavior of doxorubicin hydrochloride from medicated fibers prepared by emulsion-electrospinning. Eur. J. Pharm. Biopharm. 2008, 70, 165-170. [CrossRef] [PubMed]

161. Badawi, M.A.; El-Khordagui, L.K. A quality by design approach to optimization of emulsions for electrospinning using factorial and D-optimal designs. Eur. J. Pharm. Sci. 2014, 58, 44-54. [CrossRef] [PubMed]

162. Said, S.S.; Aloufy, A.K.; El-Halfawy, M.O.; Boraei, N.A.; El-Khordagui, L.K. Antimicrobial PLGA ultrafine fibers: Interaction with wound bacteria. Eur. J. Pharm. Biopharm. 2011, 79, 108-118. [CrossRef]

163. Monteiro, N.; Martins, M.; Martins, A.; Fonseca, N.A.; Moreira, J.N.; Reis, R.L.; Neves, N.M. Antibacterial activity of chitosan nanofiber meshes with liposomes immobilized releasing gentamicin. Acta Biomater. 2015, 18, 196-205. [CrossRef]

164. Huang, Z.M.; He, C.L.; Yang, A.; Zhang, Y.; Han, X.-J.; Yin, J.; Wu, Q. Encapsulating drugs in biodegradable ultrafine fibers through co-axial electrospinning. J. Biomed. Mater. Res. A 2006, 77, 169-179. [CrossRef]

165. Akhgari, A.; Heshmati, Z.; Makhmalzadeh, B.S. Indomethacin electrospun nanofibers for colonic drug delivery: Preparation and characterization. Adv. Pharm. Bull. 2013, 3, 85-90. [PubMed]

166. Jiang, Y.N.; Mo, H.Y.; Yu, D.G. Electrospun drug-loaded core-sheath PVP/zein nanofibers for biphasic drug release. Int. J. Pharm. 2012, 438, 232-239. [CrossRef] [PubMed]

167. Thakur, R.A.; Florek, C.A.; Kohn, J.; Michniak, B.B. Electrospun nanofibrous polymeric scaffold with targeted drug release profiles for potential application as wound dressings. Int. J. Pharm. 2008, 364, 87-93. [CrossRef]

168. Zong, X.; Kim, K.; Fang, D.; Ran, S.; Hsiao, B.S.; Chu, B. Structure and process relationship of electrospun bioabsorbable nanofiber membranes. Polymer 2002, 43, 4403-4412. [CrossRef] 
169. Zamania, M.; Morsheda, M.; Varshosazb, J.; Jannesari, M. Controlled release of metronidazole benzoate from polye-caprolactone electrospun nanofibers for periodontal diseases. Eur. J. Pharm. Biopharm. 2010, 75, 179-185. [CrossRef] [PubMed]

170. Li, X.; Wang, C.; Yang, S.; Liu, P.; Zhang, B. Electrospun PCL/mupirocin and chitosan/lidocaine hydrochloride multifunctional double layer nanofibrous scaffolds for wound dressing applications. Int. J. Nanomed. 2018, 13, 5287. [CrossRef]

171. Park, C.G.; Kim, E.; Park, M.; Park, J.H.; Choy, Y.B. A nanofibrous sheet-based system for linear delivery of nifedipine. J. Control. Release 2011, 149, 250-257. [CrossRef]

172. Xie, J.; Wang, C.H. Electrospun micro- and nanofibers for sustained delivery of paclitaxel to treat C6 glioma in vitro. Pharm. Res. 2006, 23, 1817-1826. [CrossRef]

173. Ruckh, T.T.; Oldinski, R.A.; Carroll, D.A.; Mikhova, K.; Bryers, J.D.; Popat, K.C. Antimicrobial effects of nanofiber poly (caprolactone) tissue scaffolds releasing rifampicin. J. Mater. Sci. 2012, 23, 1411-1420. [CrossRef]

174. Zupančič, Š.; Baumgartner, S.; Lavrič, Z.; Petelin, M.; Kristl, J. Local delivery of resveratrol using polycaprolactone nanofibers for treatment of periodontal disease. J. Drug Deliv. Sci. Technol. 2015, 30, 408-416. [CrossRef]

175. Figueira, D.R.; Miguel, S.P.; de Sá, K.D.; Correia, I.J. Production and characterization of polycaprolactonehyaluronic acid/chitosan-zein electrospun bilayer nanofibrous membrane for tissue regeneration. Int. J. Biol. Macromol. 2016, 93, 1100-1110. [CrossRef] [PubMed]

176. Unnithan, A.R.; Gnanasekaran, G.; Sathishkumar, Y.; Lee, Y.S.; Kim, C.S. Electrospun antibacterial polyurethane-cellulose acetate-zein composite mats for wound dressing. Carbohydr. Polym. 2014, 102, 884-892. [CrossRef] [PubMed]

177. Liao, N.; Unnithan, A.R.; Joshi, M.K.; Tiwari, A.P.; Hong, S.T.; Park, C.-H.; Kim, C.S. Electrospun bioactive poly ( $\varepsilon$-caprolactone)-cellulose acetate-dextran antibacterial composite mats for wound dressing applications. Colloids Surf. A Physicochem. Eng. Asp. 2015, 469, 194-201. [CrossRef]

178. Kenawy, E.-R.; Bowlin, G.L.; Mansfield, K.; Layman, J.; Simpson, D.G.; Sanders, E.H.; Wnek, G.E. Release of tetracycline hydrochloride from electrospun poly (ethylene-co-vinyl acetate), poly (lactic acid), and a blend. J. Control. Release 2002, 81, 57-64. [CrossRef]

179. Alavarse, A.C.; de Oliveira Silva, F.W.; Colque, J.T.; da Silva, V.M.; Prieto, T.; Venancio, E.C.; Bonvent, J.-J. Tetracycline hydrochloride-loaded electrospun nanofibers mats based on PVA and chitosan for wound dressing. Mater. Sci. Eng. C 2017, 77, 271-281. [CrossRef]

180. Krogstad, E.A.; Woodrow, K.A. Manufacturing scale-up of electrospun poly (vinyl alcohol) fibers containing tenofovir for vaginal drug delivery. Int. J. Pharm. 2014, 475, 282-291. [CrossRef]

181. Bakhsheshi-Rad, H.R.; Ismail, A.F.; Aziz, M.; Akbari, M.; Hadisi, Z.; Daroonparvar, M.; Chen, X.B. Antibacterial activity and in vivo wound healing evaluation of polycaprolactone-gelatin methacryloyl-cephalexin electrospun nanofibrous. Mater. Lett. 2019, 256, 126618. [CrossRef]

182. Bakhsheshi-Rad, H.R.; Hadisi, Z.; Ismail, A.F.; Aziz, M.; Akbari, M.; Berto, F.; Chen, X.B. In vitro and in vivo evaluation of chitosan-alginate/gentamicin wound dressing nanofibrous with high antibacterial performance. Polym. Test. 2020, 82, 106298. [CrossRef]

183. Gerardo-Nava, J.; Führmann, T.; Klinkhammer, K.; Seiler, N.; Mey, J.; Klee, D.; Möller, M.; Dalton, P.D.; Brook, G.A. Human neural cell interactions with orientated electrospun nanofibers in vitro. Nanomedicine 2009, 11-30. [CrossRef]

184. Ghosal, K.; Thomas, S.; Kalarikkal, N.; Gnanamani, A. Collagen coated electrospun polycaprolactone (PCL) with titanium dioxide $\left(\mathrm{TiO}_{2}\right)$ from an environmentally benign solvent: Preliminary physico-chemical studies for skin substitute. J. Polym. Res. 2014, 21, 410. [CrossRef]

185. Sapru, S.; Das, S.; Mandal, M.; Ghosh, A.K.; Kundu, S.C. Prospects of nonmulberry silk protein sericin-based nanofibrous matrices for wound healing-in vitro and in vivo investigations. Acta Biomater. 2018, 78, 137-150. [CrossRef] [PubMed]

186. Tseng, Y.-Y.; Kao, Y.-C.; Liao, J.-Y.; Chen, W.-A.; Liu, S.-J. Biodegradable drug-eluting poly [lactic-co-glycol acid] nanofibers for the sustainable delivery of vancomycin to brain tissue: In vitro and in vivo studies. ACS Chem. Neurosci. 2013, 4, 1314-1321. [CrossRef] 
187. Movahedi, M.; Asefnejad, A.; Rafienia, M.; Khorasani, M.T. Potential of novel electrospun core-shell structured polyurethane/starch (hyaluronic acid) nanofibers for skin tissue engineering: In vitro and in vivo evaluation. Int. J. Biol. Macromol. 2020, 146, 627-637. [CrossRef] [PubMed]

188. Uppal, R.; Ramaswamy, G.N.; Arnold, C.; Goodband, R.; Wang, Y. Hyaluronic acid nanofiber wound dressing-production, characterization, and in vivo behavior. J. Biomed. Mater. Res. B Appl. Biomater. 2011, 97, 20-29. [CrossRef] [PubMed]

189. Zahedi, P.; Rezaeian, I.; Jafari, S.H. In vitro and in vivo evaluations of phenytoin sodium-loaded electrospun PVA, PCL, and their hybrid nanofibrous mats for use as active wound dressings. J. Mater. Sci. 2013, 48, 3147-3159. [CrossRef]

190. Thanh, N.T.; Hieu, M.H.; Phuong, N.T.M.; Thuan, T.D.B.; Thu, H.N.T.; Minh, T.D.; Dai, H.N.; Thi, H.N. Optimization and characterization of electrospun polycaprolactone coated with gelatin-silver nanoparticles for wound healing application. Mater. Sci. Eng. C 2018, 91, 318-329. [CrossRef]

191. Pal, P.; Das, B.; Dadhich, P.; Achar, A.; Dhara, S. Carbon nanodot impregnated fluorescent nanofibers for in vivo monitoring and accelerating full-thickness wound healing. J. Mater. Chem. B 2017, 5, 6645-6656. [CrossRef]

192. Augustine, R.; Nethi, S.K.; Kalarikkal, N.; Thomas, S.; Patra, C.R. Electrospun polycaprolactone (PCL) scaffolds embedded with europium hydroxide nanorods (EHNs) with enhanced vascularization and cell proliferation for tissue engineering applications. J. Mater. Chem. B 2017, 5, 4660-4672. [CrossRef]

193. Augustine, R.; Dominic, E.A.; Reju, I.; Kaimal, B.; Kalarikkal, N.; Thomas, S. Electrospun polycaprolactone membranes incorporated with $\mathrm{ZnO}$ nanoparticles as skin substitutes with enhanced fibroblast proliferation and wound healing. Rsc Adv. 2014, 4, 24777-24785. [CrossRef]

194. Sadri, M.; Arab Sorkhi, S. Preparation and characterization of CS/PEO/cefazolin nanofibers with in vitro and in vivo testing. Nanomed. Res. J. 2017, 2, 100-110.

195. Kai, D.; Liow, S.S.; Loh, X.J. Biodegradable polymers for electrospinning: Towards biomedical applications. Mater. Sci. Eng. C 2014, 45, 659-670. [CrossRef] [PubMed]

196. Xue, J.; He, M.; Liang, Y.; Crawford, A.; Coates, P.; Chen, D.; Shi, R.; Zhang, L. Fabrication and evaluation of electrospun PCL-gelatin micro-/nanofiber membranes for anti-infective GTR implants. J. Mater. Chem. B 2014, 2, 6867-6877. [CrossRef]

197. Yang, X.; Yang, J.; Wang, L.; Ran, B.; Jia, Y.; Zhang, L.; Yang, G.; Shao, H.; Jiang, X. Pharmaceutical intermediate-modified gold nanoparticles: Against multidrug-resistant bacteria and wound-healing application via an electrospun scaffold. ACS Nano 2017, 11, 5737-5745. [CrossRef] [PubMed]

198. Wang, Y.; Li, P.; Xiang, P.; Lu, J.; Yuan, J.; Shen, J. Electrospun polyurethane/keratin/AgNP biocomposite mats for biocompatible and antibacterial wound dressings. J. Mater. Chem. B 2016, 4, 635-648. [CrossRef] [PubMed]

199. Farokhi, M.; Mottaghitalab, F.; Fatahi, Y.; Khademhosseini, A.; Kaplan, D.L. Overview of silk fibroin use in wound dressings. Trends Biotechnol. 2018, 36, 907-922. [CrossRef] [PubMed]

200. Hidalgo Pitaluga, L.; Trevelin Souza, M.; Dutra Zanotto, E.; Santocildes Romero, M.E.; Hatton, P.V. Electrospun F18 bioactive Glass/PCL—Poly ( $\varepsilon$-caprolactone)—Membrane for guided tissue regeneration. Materials 2018, 11, 400. [CrossRef] [PubMed]

201. Ferrández-Rives, M.; Beltrán-Osuna, Á.A.; Gómez-Tejedor, J.A.; Gomez Ribelles, J.L. Electrospun PVA/bentonite nanocomposites mats for drug delivery. Materials 2017, 10, 1448. [CrossRef]

202. Stepanova, A.O.; Laktionov, P.P.; Cherepanova, A.V.; Chernonosova, V.S.; Shevelev, G.Y.; Zaporozhchenko, I.A.; Karaskov, A.M.; Laktionov, P.P. General study and gene expression profiling of endotheliocytes cultivated on electrospun materials. Materials 2019, 12, 4082. [CrossRef]

203. De Siqueira, L.; Ribeiro, N.; Paredes, M.; Grenho, L.; Cunha-Reis, C.; Trichês, E.S.; Fernandes, M.H.; Sousa, S.R.; Monteiro, F.J. Influence of PLLA/PCL/HA scaffold fiber orientation on mechanical properties and osteoblast behavior. Materials 2019, 12, 3879. [CrossRef]

204. Mukheem, A.; Muthoosamy, K.; Manickam, S.; Sudesh, K.; Shahabuddin, S.; Saidur, R.; Akbar, N.; Sridewi, N. Fabrication and characterization of an electrospun PHA/graphene silver nanocomposite scaffold for antibacterial applications. Materials 2018, 11, 1673. [CrossRef]

205. Rahman, S.U.; Nagrath, M.; Ponnusamy, S.; Arany, P.R. Nanoscale and macroscale scaffolds with controlled-release polymeric systems for dental craniomaxillofacial tissue engineering. Materials 2018, 11, 1478. [CrossRef] [PubMed] 
206. Kurtz, I.S.; Schiffman, J.D. Current and emerging approaches to engineer antibacterial and antifouling electrospun nanofibers. Materials 2018, 11, 1059. [CrossRef]

207. Ciraldo, F.E.; Liverani, L.; Gritsch, L.; Goldmann, W.H.; Boccaccini, A.R. Synthesis and characterization of silver-doped mesoporous bioactive glass and its applications in conjunction with electrospinning. Materials 2018, 11, 692. [CrossRef] [PubMed]

208. Park, S.C.; Yuan, Y.; Choi, K.; Choi, S.O.; Kim, J. Doxorubicin release controlled by induced phase separation and use of a co-solvent. Materials 2018, 11, 681. [CrossRef] [PubMed]

209. Batool, F.; Morand, D.N.; Thomas, L.; Bugueno, I.M.; Aragon, J.; Irusta, S.; Keller, L.; Benkirane-Jessel, N.; Tenenbaum, H.; Huck, O. Synthesis of a novel electrospun Polycaprolactone scaffold functionalized with ibuprofen for periodontal regeneration: An in vitro andin vivo study. Materials 2018, 11, 580. [CrossRef]

210. Wu, D.; Samanta, A.; Srivastava, R.K.; Hakkarainen, M. Nano-graphene oxide functionalized bioactive poly (lactic acid) and poly ( $\varepsilon$-caprolactone) nanofibrous scaffolds. Materials 2018, 11, 566. [CrossRef]

211. Abudula, T.; Gzara, L.; Simonetti, G.; Alshahrie, A.; Salah, N.; Morganti, P.; Chianese, A.; Fallahi, A.; Tamayol, A.; Bencherif, S.A.; et al. The effect of poly (glycerol sebacate) incorporation within hybrid chitin-lignin sol-gel nanofibrous scaffolds. Materials 2018, 11, 451. [CrossRef]

212. Yang, F.; Miao, Y.; Wang, Y.; Zhang, L.M.; Lin, X. Electrospun zein/gelatin scaffold-enhanced cell attachment and growth of human periodontal ligament stem cells. Materials 2017, 10, 1168. [CrossRef]

213. Chen, Y.; Yang, W.; Wang, W.; Zhang, M.; Li, M. Bombyx mori silk fibroin scaffolds with antheraea pernyi silk fibroin micro/nano fibers for promoting EA. hy926 cell proliferation. Materials 2017, 10, 1153. [CrossRef]

214. Norman, J.J.; Tejal, A.D. Methods for fabrication of nanoscale topography for tissue engineering scaffolds. Ann. Biomed. Eng. 2006, 34, 89-101. [CrossRef]

215. Kundrat, V.; Cernekova, N.; Kovalcik, A.; Enev, V.; Marova, I. Drug release kinetics of electrospun PHB meshes. Materials 2019, 12, 1924. [CrossRef] [PubMed]

216. Petrova, V.A.; Chernyakov, D.D.; Poshina, D.N.; Gofman, I.V.; Romanov, D.P.; Mishanin, A.I.; Golovkin, A.S.; Skorik, Y.A. Electrospun bilayer Chitosan/Hyaluronan material and its compatibility with mesenchymal stem cells. Materials 2019, 12, 2016. [CrossRef] [PubMed]

217. Campiglio, C.E.; Contessi Negrini, N.; Farè, S.; Draghi, L. Cross-Linking strategies for electrospun gelatin scaffolds. Materials 2019, 12, 2476. [CrossRef]

218. Zhu, Z.; Zhang, Y.; Zhang, Y.; Shang, Y.; Zhang, X.; Wen, Y. Preparation of PAN@ TiO 2 nanofibers for fruit packaging materials with efficient photocatalytic degradation of ethylene. Materials 2019, 12, 896. [CrossRef] [PubMed]

219. Muthoka, R.M.; Kim, H.C.; Kim, J.W.; Zhai, L.; Panicker, P.S.; Kim, J. Steered pull simulation to determine nanomechanical properties of cellulose nanofiber. Materials 2020, 13, 710. [CrossRef]

220. Blachowicz, T.; Ehrmann, A. Conductive electrospun nanofiber Mats. Materials 2020, 13, 152. [CrossRef]

221. Salazar-Aranda, R.; Pérez-Lopez, L.A.; Lopez-Arroyo, J.; Alanís-Garza, B.A.; Waksman de Torres, N. Antimicrobial and antioxidant activities of plants from northeast of mexico. Evid.-Based Complement. Altern. Med. 2011, 2011, 2-6. [CrossRef]

222. He, Q. Antibacterial activity of traditional herbal medicine. Access Microbiol. 2019, 1. [CrossRef]

223. Wińska, K.; Mączka, W.; Łyczko, J.; Grabarczyk, M.; Czubaszek, A.; Szumny, A. Essential oils as antimicrobial agents-Myth or Real Alternative? Molecules 2019, 24, 2130. [CrossRef]

224. Zhao, Y.; Li, H.; Wei, S.; Zhou, X.; Xiao, X. Antimicrobial effects of chemical compounds isolated from traditional chinese herbal medicine (TCHM) against drug-resistant bacteria: A review paper. J. Med. Chem. 2019, 19, 125-137. [CrossRef]

(C) 2020 by the authors. Licensee MDPI, Basel, Switzerland. This article is an open access article distributed under the terms and conditions of the Creative Commons Attribution (CC BY) license (http://creativecommons.org/licenses/by/4.0/). 